\title{
DISTILLING AGENCY IN BIM-INDUCED CHANGE IN WORK PRACTICES
}

\section{Adeyemi Akintola, Senthilkumar Venkatachalam, David Root, Akponanabofa Oti}

Purpose: Critics of claims about BIM's capability to revolutionise construction industry practices, describe it as overhyped, fallacious, and therefore suggest that there is need for a more critical examination of its' change impacts. Others have posited that the changes BIM induces are evolutionary rather than revolutionary. In this vein, a careful analysis of the nature of such changes was undertaken to distil actual changes that happened, and the type of agency that brings such changes about.

Design: Drawing from appropriate qualitative research strategies, data was collected through key informant interviews from consulting organisations in South Africa that have implemented BIM within their organisations and on projects.

Findings: Changes in organisations' work practices were evident in their workflows, formal/informal methods of interaction, norms, leadership and authority structures, remuneration, and the way work was conceived or conceptualised. Furthermore, changes in organisational work practices do not solely occur through the direct agency of the BIM tool's implementation. Instead, BIM-induced change occurs by delegated, conditional and needs-based agency - which are not mutually exclusive.

Originality: The nature of changes in professional work practices could be misconstrued as being solely due to the actions of agents who actively participate in implementing BIM. The discussion in the literature has been advanced from general to specific theoretical understandings of BIM-induced change, that emphasise the need for construction stakeholders to actively participate in developing the innovations that drive 
change in the industry rather than hand the power to drive change to BIM authoring and management application developers who have less stake in the industry.

Keywords: BIM, constraints, change, agency, activity theory, work practices

\section{INTRODUCTION}

The construction industry has always contended with fragmentation; indeed, it is inherent in its' structuring, a product of the separation between design and construction, and linked to the continued specialisation of industry practices into ever more specific fields (Borg, 2005; Howard et al., 1989; Nawi et al., 2013). Master craftsmanship has given way to splitting the responsibility for design and construction project delivery processes; although, recently there are indications of a drive back towards more integrated practices globally to improve the efficiency of project delivery processes. In particular, achieving optimal project outcomes an elusive pursuit in the construction industry - is tied to making fundamental changes in the project delivery processes (Egan, 1998; Latham, 1994), as well as the application of suitable technology.

Rooted in Computer-Aided Design (CAD), BIM has been demonstrated, to a reasonable extent, as being capable of improving many aspects of project delivery (Crotty, 2012; Deutsch, 2011; Yalcinkaya and Singh, 2015). Understandably, the adoption of BIM is being primarily driven by expectations of its' benefits. These include time and cost savings (Fan et al., 2013; Suermann and Issa, 2009), reduction of rework, and increased productivity (Love et al., 2011). BIM uptake is also expected to facilitate the ability of multidisciplinary and multifunctional teams to cope with difficult situations that emerge at various project stage boundaries, 
thereby improving efficiencies (Sackey and Akotia, 2017). Based on these benefits, governments in various countries have begun to openly adopt BIM to oversee the creation and management of information throughout the project lifecycle (Arayici et al., 2012; Herr and Fischer, 2019; Vidalakis et al., 2019; Yuan and Yang, 2019). However, there have been criticisms levelled at claims about the capability of BIM to revolutionise construction industry practices. Rather, some of these are perceived as being overhyped and fallacious. Furthermore, there are questions about whether BIM adoption can really bring about desired changes in organisational work culture, and importantly, the individual stakeholders' roles in instigating such changes. The critical gap is, first, one of a theoretical nature the need for nuance in the existing and emerging explanations of the diverse forms of change the industry is experiencing. This is also evident, for instance, in the recent BIM literature (Akintola et al., 2017, 2020; Çıdık et al., 2017; Dainty et al., 2017; Fox, 2014; Papadonikolaki and Wamelink, 2017; Sherratt et al., 2020). It is with this ongoing theoretical discourse that we have sought to engage.

It is, therefore, essential to investigate the nature of organisational changes induced by BIM uptake, in order to distil the types of changes that occur and the agency that brings about such changes. Through a careful analysis, the paper adds to knowledge in that BIM induced changes are often made necessary or happen due to constraints experienced while implementing it and its enablement of more effective work routines and that different types of agency are responsible for bringing about such changes. We demonstrate that BIMinduced changes occur not solely by the direct agency of BIM tool implementation but by delegated, conditional and needs-based agency. This was achieved by uncovering the path and pattern of changes in work practices experienced by consulting professional 
organisations, who may have been first adopters of BIM in South Africa. It employs interpretive theoretical explanations to explore the occurrence of changes, and the nature of the agency and agents involved. To understand the changes, the study analysed how a change occurs when BIM is implemented. The theoretical basis for this approach is discussed, along with an overview of the relevant BIM literature, the methodological issues and the rationale for the choices made. These are followed by a descriptive analysis of the data collected, revealing the changes that have occurred after BIM was implemented. Further, discussions on how the changes occur and theoretical interpretation of the data - mainly based on Kapterlinin and Nardi's (2006) theoretical positions on agency and changes in work practices - are presented. In addition to the Introduction, these aspects have been captured in four other sections: a Literature Review to appraise existing works, summarise the broad concepts and establish the research need; Methods, describing the research design; Discussion of the findings; Implication of BIM-induced changes and the Conclusion.

\section{LITERATURE REVIEW}

To achieve the full potential of BIM in the construction industry, implementers will be required to overcome several challenges (Crotty, 2012; Jung and Joo, 2011; Porwal and Hewage, 2013) These challenges can occur in the delivery process in socio-cultural and technology domains, and often require changes to be made. Thus, several changes are needed at the organisational, team and institutional levels on one hand; while on the other, BIM in and of itself induces several changes at all three levels. Though claims about BIM's impacts are well documented in the literature, several of them have been labelled as hype and fallacies by authors like Fox (2014). Up until the present, however, the BIM literature has 
been mostly uncritical and lacking in sound theoretical foundations, except for typical applications of theories that explain technology adoption and use.

Current research in BIM has focussed on critically examining claims about the impacts and potentials of BIM implementation. These studies are stimulating new research questions about the 'technocratic optimism' that often dominates current debates around BIM and its' implementation (Dainty et al., 2017). For instance, Dainty et al. (2017) scrutinised the enthusiasm surrounding BIM and assertions about its' revolutionary impact on construction industry practices. They argued that it is still vital to complement institutional explanations of BIM adoption, with a focus on 'the firm' and its' people. Likewise, using theoretical perspectives drawn from activity theory and institutional theory, Akintola et al. (2017) critically examined how changing roles and the creation of new BIM roles, impacts on power dynamics within teams, and also questioned the sustainability of new BIM management roles. Meanwhile, Cidik et al. (2017), in a similar approach to Dainty et al. (2017), argued for the importance of nuanced and critical understandings of the changing logic of work practices; while Akintola et al. (2020) posited that BIM change impacts are evolutionary rather than revolutionary.

Whilst acknowledging the potential of BIM to significantly impact or even transform construction industry work practices, as Dainty et al. (2017) and other authors have done, this study situates itself in a contemporary discourse that seeks to provide nuanced explanations of BIM-induced change in organisations' work practices. Dainty et al. (2017) raised important questions in this regard, asserting that surveys of BIM implementation usually indicate that it requires changes in work practices, but do not show whether such changes are happening nor 
report their real impacts. Also, they acknowledged the need to examine BIM implementation from the viewpoints of the organisations that put it into practice.

It could be argued further that when BIM is implemented, the intention is typically not to effect change in professional work practices per se, but rather to realise the benefits that it can provide. However, along with its' implementation within organisations and teams come constraints and enabling factors which inadvertently induce changes in work practices. Though some of the claims made in the literature about BIM's capability to revolutionise construction industry practices are not unfounded, it is important to develop nuanced practical and theoretical explanations of changes in work practices and how such changes came to be; and thus asking, by what agency? In this context, agency means an agent's whether human or nonhuman - capacity to act or cause an effect (Kaptelinin \& Nardi 2006). Accordingly, the main question posed in this paper is: by what means does change happen when BIM is implemented? This question leans on theorist Kuutti's (1999) assertion that new approaches are required to understand such changes. Furthermore, it is also important to theorise change in work practices by explaining the forms of agency that make the changes happen as demonstrated in this paper.

\subsection{Theoretical perspectives of BIM-related changes induced in work practices}

Many theories apply to information systems-related research. However, to make sense of the socio-cultural nature of human actions relative to their use of technology, it is pertinent to explore organisational or institutional theories, especially since the complex BIM implementation issues are people- and process-related. The principal concern of this paper is 
to develop an in-depth understanding of changes in work practices when new technology and associated processes are introduced into established work routines.

This paper draws from cultural-historical activity theory. Activity theory seeks to aid understanding of purposeful human interaction (Kaptelinin and Nardi, 2006), and is considered appropriate for studies investigating interrelationships within human activity that employs information technology (such as BIM) as an enabler (Crawford and Hasan, 2006; Kaptelinin and Nardi, 2006). The theory enables the analysis of emerging patterns of human activity in terms of changing processes (Crawford and Hasan, 2006). It has also been proposed as a means for making sense of the ways in which people act together with the assistance of tools, and in complex dynamic environments (Crawford and Hasan, 2006).

The theory is suited to developing holistic conceptualisations of emerging patterns of human activity (Crawford and Hasan, 2006), and investigating interrelationships between the different constituents of work activities. Human activity is comprised of an interconnected system of actors, the subject of their work (mediated by tools, both mental and material), rules guiding their work, roles, and the community of practice within which such work takes place and impacts upon (Engestrom, 2000; Kaptelinin and Nardi, 2006). Activity systems are internally contradictory, and a change in one element of the system may propagate change in other elements (Engestrom, 2000; Engeström and Escalante, 1996; Kaptelinin and Nardi, 2006). This is similar to the position taken by Geels (2002) in a study of technological transitions and changes in user practices, infrastructure, industrial networks, and culture.

Leaning on arguments from activity theory, this paper proposes that the implementation of new technology (constituting a change in an element of the activity), can create constraints 
within either an organisational or project team activity system. Furthermore, that change and development of the activity system(s), can be accounted for in the constraints produced by the implementation of BIM, the demands for change created in the existing ways of working, and their resolution (Engestrom, 2000; Kaptelinin and Nardi, 2006).

\section{Figure 1: Conceptual model (a)}

Therefore, in this first version of the conceptual model (Figure 1), it is posited based on activity theory, that dysfunctions in an activity system create needs states within the system, and that their resolution paves the way for change within organisational structures. This model explains the relationship between the basic theoretical concepts.

Also, to explain the nature of the stimuli for BIM-induced change, philosophical perspectives on agency prove useful; particularly those that explain a non-monolithic view of agency in terms of agentic entities and their capacity to effect change. Morrisey (2003) describes agency as the capacity of an entity in a given environment, to enact either involuntary or conscious goal directed actions. Hence the dialectic schism between intentional and non-intentional agency. These ideas are also linked to the possibility to view an agent as either human or nonhuman. Human agency is easy to fathom and understand. However, some theories have considered the possibility of recognising the agentive attributes of non-human entities, because of their ability to act through representative agents (Morrissey, 2003). An obvious example of this concept could be the agentive attributes of Artificial Intelligence. In this vein, Bowden (2015) has broached the subject of unravelling the relationship between human and non-human agency. This is a step away from the characterisation of agency as exclusively human, neglecting the recognition of non-anthropocentric approaches to understanding agency. 
Some scholars of BIM have sought to position the discourse around BIM implementation within a socio-cultural context. For example, Poirier et al. (2017) aimed to explain BIM impacts through a self-developed analytical framework comprising the structure, artefacts, agents, process, expectations, requirements, and capabilities among others, in related processes. These are not new concepts within work development theory, and an activity theory perspective can provide more holistic and formal explanations of changes in tool-mediated work activities. Therefore, in this study, experiences of constraints that could expose unique aspects of the changes in the logic of work practices, were sought. Furthermore, the authors attempt to align the perspectives from agency and activity theory.

\subsection{Organisations management systems and innovation}

It is essential to consider an organisation's structure and management system in assessing its innovation adoption and performance. Damanpour (1991) found statistically significant positive associations between organisation innovation and specialisation, professionalism, and technical knowledge and resources, and centralisation. Cosh et al. (2012) examined this relationship and found that decentralised decision making, which bottom up adoption of BIM could be a product of, as well as formal written plans support the ability to innovate and by extension make the necessary changes to successfully adapt. Offering a different perspective, and in line with the theory, Suchan (2006) posits that change is either viewed as a natural often unnoticed evolution or a product of deliberate intention to design and effect change. This is often the case with technologically induced change, which is many times reactive and gradual rather than teleological large scale where objectives are measured as the change takes place. BIM change is often reactive and driven mainly by agents or professionals who have the responsibility to implement it within organisations and on projects. 
Understanding BIM induced change requires, first, an understanding of the context within which change typically begins, the organisational structure, and routines. Feldman and Penland (2003) challenged the continual view of organisational work and in particular, distinguished between the ostensive and performative dimensions of work routines, the former being related to what is recognised as structure, and the latter, what is known to be the specific work operations. Certainly, change in organisations due to innovation are firstly effected in the performative aspect of work routines and after that, become embedded or evolve into the ostensive dimension that shape the form of organisational structures. Therefore, the carrying out of professional work is situated in the complex context of the broader organisational structure.

Blayse and Manley's (2004) study identified six main constraints to construction innovation as: (i) clients and manufacturers; (ii) structure of production; (iii) relationships between individuals and organisations within the industry/external parties; (iv) procurement systems; (v) regulations/standards; and (vi) the nature and quality of relevant organisational resources. Among the six, (iii) and (vi) are of interest here. Employees' capabilities are largely a function of the relationships developed between the individual and the organisation (iii), which is closely related to the organisational resources (vi) at the individual's disposal. The maturity of such capabilities, in turn, depends on the individual's proficiency and willingness to learn. As Walker (2016) points out, organisational learning through collaboration, professional reflective practices, and a better understanding of IT applications in redefining data, information and knowledge boundaries, are two important foci to enhance the effective diffusion of innovative practices across markets. In expanding BIM research and delivery foundation framework (Succar, 2009) for industry stakeholders, macro-BIM adoption models 
have been suggested (Succar and Kassem, 2015) for a broader assessment of innovations on BIM implementation and diffusion. One main concern and limitation associated with the macro-BIM studies, is that it has not linked BIM diffusion well enough to market-driven social variables. To this end, this paper examines social issues surrounding changes induced by BIM implementation.

In Leight and Fennell's (1997) attempt to stimulate 'sociological interest in professional work, they drew an important distinction between professional work and the larger work place which would include, essentially, supporting departments (e.g. Human Resources and Finance) and professionals other than those who perform the core function of the organisation. However, they emphasised the importance of understanding professional work to understanding the entire workplace. This means that professional work can be studied separately from the larger workplace; it is on the professional work routines of those who perform the core function of professional organisations that this study mainly focuses on.

Feldman and Pentland (2003) identified one of the problems of theorising organisation routines as the omission of agency. It is to this kind of need that this study responds. In other words, there ismore focus on the work of professionals who perform the core function of the organisation; for example, the performance of a new BIM-based information exchange function which is situated within a complex, larger workplace environment to which this work remains sensitive. 


\subsection{BIM implementation constraints and claims of change-inducing capabilities}

Without further rehashing the abundant literature on BIM implementation constraints and its change-inducing capabilities, this study builds on the previous works of researchers like Taylor and Bernstein (2009), who emphasise the need to focus on the evolution of interorganisational business practices and their adaptation to change; Sebastian's (2011) assertion that effective multidisciplinary collaboration through BIM, requires changing roles, contractual relationships, processes, and mindset; Arayici et al.'s (2012) affirmation of the need for comprehensive change management to achieve BIM benefits; the argument by Hartman et al. (2012) on the technological push-pull aspects of BIM implementation; Fox's (2014) criticism of the lack of critical discourse on BIM and, more recently, the works of Cidik et al. (2017) and Dainty et al. (2017) in the same vein. Some of the authors who have responded to this challenge in the past couple of years include Papadonikolaki et al. (2019), who rightly challenged the prevalent view of BIM as an artefact; even though from an activity theory perspective, the now common view of BIM as a process could make the industry lose sight of the mediating function of BIM (as a tool) in shaping an activity and its constituent elements - which in fact captures the process dimension. Oraee et al. (2019) also provided a summary and conceptual model based on a review of BIM constraints.

Importantly, Sherrat et al. (2020), in their paper examined the potential impact of Construction 4.0 on construction industry professionals - and leading on from the works of Dainty et al. (2017), Azzouz and Papadonikolaki (2020) and Akintola et al. (2017) - inter alia suggested that professionals may find that their roles in the industry are more heavily influenced and shaped by technologies and that the role of the 'technology owner' - BIM authoring/management tool developers - may become more powerful than the traditional 
professions. This is an important point and pivotal to the conceptualisation of this study. Similar to Akintola et al.'s (2020) study, it is emphasised that the role of IT tools (BIM authoring/management tools) are significant in shaping or changing industry practices. Sherrat et al. (2020), admittedly, did not proffer answers to the questions raised about the indirect economic and political power held by BIM authoring tool developers, and their potential to shape or change future industry practices resulting in technology pull rather than technology push. While some of the current literature have dealt with changing power dynamics due to BIM, this study focuses on distilling agency of change. This is important to refocus attention on what is important BIM in the broader picture, beyond organisational and project level management of change.

Hitherto, we have reviewed the literature from which we deduce that there is a criticism of the BIM literature as being largely theoretical (Dainty et al., 2017; Fox, 2014) and a need yet to theorise BIM-induced change and unravel

- the social dimension of change and the call for more nuanced explanations of BIMinduced change (Kaptelinin and Nardi, 2006)

- the role of stakeholders in the change process (Akintola et al., 2017; Sherratt et al., 2020)

- $\quad$ the real impacts of BIM on organisational work practices (Dainty et al., 2017)

Thus, this paper adopts a distinctly different approach, employing interpretive theoretical explanations of how changes occur. This is intended to distil case-based experiences of change to understand the means through which work practices change when BIM is implemented. The main aim is therefore to uncover the path and pattern of work practice 
changes experienced by consulting professional organisations that, in the context of this research, were among the first adopters of BIM. There is also a unique opportunity to seek an alignment between the perspectives drawn from agency theory and activity theory to enrich the conceptual model. Following this, the paper presents interpretive theoretical accounts of how the changes experienced by BIM implementers occurred, by examining the nature of the agency or the agents involved. This approach leans on theorist Kuutti's (1999) assertion that new approaches are required to understand such changes. The methods employed - and elaborated in the Methods section - are thus suited to research drawing on activity theory, as established in the synthesis undertaken by Yamagatha-Lynch (2010).

\section{RESEARCH METHODOLOGY}

The main question posed in this paper is: how does change happen and what is the path and pattern of change in work practices when BIM is implemented? Also, we asked, by what means does change happen? Furthermore, it is also important to conceptually acknowledge and detail the roles of the human and non-human actors that make change happen. This paper has sought to uncover the theoretical and practical implications of the influence that technology developers have on ways of working in the construction industry. A 'how question' is appropriate here because of the intention to examine the change process, from stimuli to outcome. The methodology is informed, by the theoretical framework and conceptual model depicted in presented in Figure 1 and will help to refine the understanding of the existing theoretical concepts important to the study.

In-depth explanations of BIM's impact cannot be developed without involving the relevant social actors. In this case, these are the construction professionals directly involved in the 
delivery of projects, and for which the research outcomes may be useful. Furthermore, an abductive approach to research, that supports the identification of themes within collected data and locates these in a conceptual framework, was deemed appropriate. This made it essential to employ deductive and inductive approaches in the research process, to link evidence and social theory (Sæther, 1998). In this study, the object of interest was to obtain data or facts about professionals' practices and routines. In addition, interpretations of how members of the group carry out their activities was studied. Since defining mutually exclusive paradigms may not be possible(Atkinson, 1988), it was considered practical to draw eclectically, rather than following one system, from relevant paradigms (Atkinson, 1988; Miles et al., 2014). Aspects of process management and process data generation have been well researched (Succar, 2009; Succar and Kassem, 2015) and are outside the scope of this study which focuses on the theorisation of change in professional work practices based on the experiences of implementers.

In the following section, we discuss and justify the criteria for selecting cases and participants. Figure 2 presents a description of the procedure adopted for collecting and analysing the data.

Figure 2: Research Framework

\section{Case selection method}

Uptake of BIM in the South African construction industry, in common with other African countries, has been slower than has been observed in Europe and North America (Froise and Shakantu, 2014; Harris, 2016). Thus, few organisations have been implementing BIM beyond the level of standalone applications for producing designs within their organisations. The approach to sampling was, therefore, a nested strategy which consisted of two levels of 
purposive sampling (Patton, 2015) - a strategy endorsed by Yin (2014). This included, first, selection of organisations and then key informants within them.

While the primary interest was in cases of organisations, data could be collected about them from individual interviews to examine how such organisations work, and also how and why phenomena of interest occur within the organisation. First, comparison-focused case sampling (Patton, 2015) was done. Through this, cases of professional construction organisations that have implemented BIM within their organisation and on multidisciplinary projects, were purposely selected. These included extreme deviant cases of relatively high success at implementing BIM and a notable failure at implementing BIM (Patton, 2015; Wengraf, 2001). Five of the cases were multidisciplinary organisations (i.e., inclusive of Architects, Quantity surveyors, Services Engineers, and Structural Engineers) and three were Architectural firms. Since detailed profile description is a requirement for justifying key informant selection (Marshall, 1996; Tremblay, 1957), a detailed profile of each case is shown in Table 2. Overall, the adopted methodology is not dissimilar to the works of authors whose studies we have engaged with as can be seen in Table 1.

\section{Table 1. Research methodologies of similar studies}

For a study like this, Patton (2015) affirmed that the determination of a suitable number of cases depends on the purpose of the enquiry and availability of such cases. A further tradeoff is also required between the depth and breadth of data collected and its analysis (Patton, 2015). Also, Patton (Patton, 2015) supported the idea that fewer than four cases is not enough, while more than ten cases may be too much - he then cites several examples of fielddefining studies that have employed sample sizing that lie between the two. 


\subsection{Key Informants' profile}

Participants were selected within the organisations to fit into pre-set characteristics, as shown in Table 2. These characteristics qualify them as key informants for gathering information that is capable of providing insight into the problem area (Marshall, 1996; Tremblay, 1957). The participants were individuals who held responsibility for facilitating adoption, implementation and maintenance of BIM within their respective organisations. Furthermore, all the interviewees represent organisations that provide a wide range of services, while most (i.e., seven out of eight) operate internationally.

To justify the inclusion of participants as key informants, this study relies on Tremblay's (1957) rationale, which was later corroborated by Marshall (1996). This criteria includes that participants should be skilled professionals, occupy positions of influence (more than a quarter are company directors, while others were partners within their organisations) and responsibility, are exposed to and possess the relevant kinds of knowledge based on their role in the community of interest to the study and, importantly, hold a wide range of views. That is, they held views that ranged from pessimism to optimism about BIM. This research, therefore, involved extensive interviewing of a few strategically chosen participants who led the implementation within the organisations selected and were involved in the entire process. The questions posed during the interview were asked ex-post facto to reveal constraints experienced within the organisations when BIM was implemented and the actual changes in work practices as a result. This was done in order that constraints, coping mechanisms and work practice change could be linked, as informed by the model introduced in Figure 1. 
The questions asked were designed to elicit responses on experience, knowledge, feelings, and opinions, guided by the theoretical framework. Since the theory suggests that change in work practices can be understood by examining constraints, contradictions and enablement experienced when BIM is implemented, some of the critical questions sought to elicit:

- Participants' narratives about constraints and impediments experienced while implementing BIM.

- Explanations about how differently they carried out their tasks on specific BIMenabled projects executed within their organisations compared to non-BIM projects, and how they have accommodated these changes.

These were then linked to their coping mechanisms as individuals or organisations, and the changes made in their work practices.

\section{Table 2. Profile of Key Informants}

\subsection{Data collection and analysis}

Data were collected in two stages. First, three in-depth semi-structured interviews were conducted, then preliminary field notes were written immediately after each interview, to ensure initial field reflections were fresh and clear throughout the analyses. Thereafter, the pre-prepared coding structure was revised to account for field realities (Miles et al., 2014). The second stage of data collection and analysis continued with further in-depth interviews with key informants, representing some of the most prominent consulting practices in South Africa. Field notes and verbatim transcripts were prepared after that. This was followed by 
memoing and coding in both basic analytical and theoretical forms, while also repeatedly reading the transcripts.

All the coding was done systematically using qualitative data analysis software. Furthermore, conceptually ordered matrix displays of the data within and across cases were produced (Miles et al., 2014). Chains of evidence (Urquhart, 2013), either of connections between variables of interest or explanation of phenomena of interest, were constructed based on the data, after which reports were written in an iterative analytical process. Furthermore, a method called theoretical re-description or abduction, in which empirical data are redescribed using theoretical concepts through thought operation (Ravitch and Riggan, 2012) was adopted in this study. This process involved making inferences, wherein a phenomenon or event may be interpreted from a set of theoretical ideas or concepts; and raised the level of theoretical engagement beyond the thick description of the empirical data (Fletcher, 2017). Also, of interest were objective referents (all objective information garnered during the interview interaction by the researcher as facts) and subjective referents. In this instance, it was important to ask questions to participants to elicit objective referents but merely as a means to elicit their less obvious opinions, knowledge and experiences which may lie in 'how' the participant talks about the facts. This builds off an inductive-deductive continuum that helps to shape analytical themes using the conceptual framework, and allowing the analysis to continually influence the content and structure of the conceptual framework (Ravitch and Riggan, 2012). Also, to understand change, activity theory assumptions lead one to first examine the experiences of constraints (and contradictions), the needs states (or demands for change they create), and method with which the constraints are resolved or coped with. 
This was the basis of the interaction with interviewees and the analysis of the data from which that Figure 3, and Table 4 were produced.

The typical quantitative research criteria of validity and reliability are expressed as credibility, transferability and criticality in qualitative research(Creswell, 2013). Firstly, this study follows the recommendations of Miles et al. (2014), by employing a rigorous iterative analytical process that began with the transcription of the interviews, and verbatim quotes were also used where necessary. In parts of the study where the method of analysis tended to be inductive, efforts were also made to ground the explanations in existing theory. In addition, the research questions were founded on established theory. Therefore, the conceptualisation of the research questions and methods are grounded in the same theory that also drove data collection and analysis - which followed methods proposed by Wengraf (2001) and Miles et al. (2014). That was important since the procedure followed in collecting and analysing data for qualitative research, often helps to form an opinion of research quality. Also, alternative interpretations of data are possible for all types of data. Therefore, care was taken to deeply reflect on the data in order to weigh alternative interpretations, as recognition of contrary evidence ensured that alternative arguments were embedded in the data collected and analysed. Importantly, to achieve credibility, data triangulation was the preferred strategy for which data was collected from multiple sources (Yin, 2016).

Furthermore, credibility and trustworthiness were achieved by explicit theoretical embedding. Activity theory formed the main theoretical framework for this study, from the conception of the research idea to methodology and analysis of the data. 


\section{DISCUSSION OF FINDINGS}

This section is structured in two parts. First, the context of the cases from which the findings were drawn are summarised using descriptive analysis as in Table 4, in accordance with the recommendations of Miles et al. (2014). NVivo coding and framework matrices were vital for generating these, and includes their experiences of implementing BIM which led to changes in their ways of working. Following this, a theoretical re-description and analysis of the data is presented to distil the types of agency involved, mainly based on Kaptelinin and Nardi's (2006) positions on action, activity and agency.

\subsection{The context}

The findings show that the main motives driving BIM adoption both in organisations and by project teams are the expected benefits and advantages arising from its' implementation (Cao et al., 2015). Other motivators for adoption include BIM's potential to assist in delivering on increasing client demands, and the ability of the authoring tool to provide competitive visual representations for clients when bidding for jobs. For most of the multinational firms with parent companies in Western countries, such as the UK and Netherlands, implementing BIM had for long become organisation-wide strategies for providing their services (7/8 of the organisations). This meant that they were able to draw from the expertise available outside South Africa, to help develop a strategy for implementing BIM within their branches in the country.

The findings also suggest that the top-down approach to implementation is one that leads to success (Hartmann et al., 2012), both within the organisations and on multi-organisational 
projects where the client takes responsibility for driving BIM implementation. As informant Q11 put it:

It must be a top-down approach. Our directors, even though they are not BIM users, have a lot of foresight and that's also why I think ORG 3 as a company has grown so quickly and so successfully...If you don't have that top-down (approach), it's costly to implement, and it takes time for people (staff) to become efficient.

This is despite the literature on organisational innovation performance suggesting that centralised decision-making system has a significant, but negative association with organisational innovation performance (Cosh et al., 2012). Furthermore, considering the key leadership position architects often take on projects, adoption by other professions flowed naturally from architectural practices to other disciplines.

\section{Table 3. BIM adoption properties}

It is noteworthy that $\boldsymbol{O R G}$ 6, a multidisciplinary organisation has discontinued implementing BIM, after experiencing severe difficulties and frustrations while using BIM authoring software to do work that seemed simpler using CAD software. This can be linked to user attitudes to technological innovations (Blayse and Manleys, 2004), lack of sufficient technical support and a lack of formal organisational strategies to support the implementation despite the huge spending on the procurement of BIM authoring software (Xu et al., 2014). Notably, Cosh et al. (2012) found that technological resources (human and otherwise) are critical to organisations' innovation performance. It is also remarkable that half of the organisations had drawn up formal plans to implement BIM (as in Table 3). These are mainly multinational organisations with parent companies in Western countries. They, therefore, benefitted greatly from support by company branches situated outside South Africa. 
Notably, ORG 1 and ORG 4, while not having formal organisation plans for BIM at the outset, took on a more formal approach later, as implementing BIM became a next level developmental strategy for the organisation. BIM managers were then employed to facilitate day-to-day development of BIM within the organisation, alongside content and standards development.

\subsection{Experiences of BIM implementation constraints}

ORG 3 and ORG 6 constituted typical cases that occupy opposing extremes of a spectrum of BIM implementation experiences. ORG 6 adopted BIM within the organisation about five years prior, as a decision made by top management. Currently, the implementation has failed and been discontinued entirely, with complete reversion to legacy methods (based on CAD) for providing their services. This case was essential in identifying the reasons why implementing BIM within an organisation might fail. Several reasons may be adduced in explaining the implementation's failure. These include their lack of a formal organisational plan to implement BIM within their organisation, lack of trust in training and support for professionals (Cosh et al., 2012).

Their experiences were in stark contrast to those of $\boldsymbol{O R G}$ 3. Within $\boldsymbol{O R G}$ 3, all their projects were executed based on coordinated BIM models (visualisation, collaboration, simulations, model integration, and up to schedule modelling and simulation) and with the buy-in of all project participants. In their case, BIM was adopted formally and communicated as a new way of working from top management down the organisation's hierarchy. They also developed guidelines and execution plans for multidisciplinary construction projects and the creation of new BIM management roles. 
Many of the challenges experienced at the organisational level extend to the project team level. This, as with the analysis on organisational dimension of the challenges, is in line with the main theoretical thrust of this study in that the responses to dysfunctions and subsequent demands created in the system of project team work practices, are the motivating forces for change and development of the activity (Engestrom, 2000; Kaptelinin and Nardi 2006). That is one of the key reasons why it was important to elicit BIM challenge response/coping mechanisms from the participants through objective and subjective referents.

Further, a holistic examination of informant accounts of their experiences in implementing BIM, suggests a strong link between organisational level BIM implementation experiences and team level experiences - after all, it all starts from within individual organisations that have decided to implement BIM. Therefore, the consequences of BIM challenges experienced within organisations are felt more at the inter-organisational team level. Evidently, the challenges being experienced by organisations are inextricably linked to levels of knowledge, skills, and proficiency. These, further trickle down to impact on interoperability of interorganisational business processes and the level of integration within BIM-enabled projects.

There are two key challenges identified in the analysis of participants' account of their experiences and subsequent researcher reflection. First, the varying levels of proficiency or experiential knowledge of BIM authoring/management tools and BIM processes by project participants in the recent experiences of the team members. This is strongly connected to non-interoperability of organisations' business processes on BIM-enabled projects; and inevitably has a knock-on effect on information flow and poses questions to the achievability of the potentials for which BIM is being widely advocated. Second, the lack of uniform standards, specifications and protocols for executing BIM-enabled projects is one of the 
greatest challenges, second only to skills deficiencies. That is, when compared to the construction industries in the developed countries where there are several parallel initiatives to standardise information and BIM practice. These findings, in part, corroborate the results of Ahn et al. (2016), who studied contractors' transformation strategies for adopting BIM. Similarly, Rezgui et al. (2013), on investigating construction stakeholders' socio-organisational and technical barriers to implementing BIM in the UK, argued that organisations need to reengineer their processes to reap the benefits of BIM. They also found that UK organisations contend with the need for training, and for rethinking organisational authority structures, responsibilities and financial arrangements.

In the next section, actual experiences of changes in work practices, as experienced and reported by the informants and in response to the demands for change created, are presented and analysed.

\subsection{Changes in organisational work practices}

Most of the participants affirmed that BIM impacts on their organisations' workflows (Gheisari and Irizarry, 2016; Gu and London, 2010; Porwal and Hewage, 2013; Rekola et al., 2010; Rogers et al., 2015). The changes in the organisations' work practices included changes in: design workflows; organisations' processes; approach to contextual design; and organisations' norms and culture regarding interactions and relationships, leadership and authority structures (BIM-savvy staff are appointed work team leaders ahead of others). Importantly, changes in how design and construction are conceived and/or conceptualised by construction professionals (cognitive changes) were evident. 
Table 4. Experiences of change within organisations and teams

Tangible changes in the way work is done (Table 4 and Figure 3), when examined in retrospect, included change in workflows as one of the most significant impacts. Although the essence of the work did not change much, the changes were more in line with how work was done. That is, old tasks are now being executed in different ways. The organisations' work objective (aligned with individual worker's motives for working) remained to deliver on clients' and projects' expectations, but using a different methodology. According to the data gathered, these changes were typically made to reflect what was in the organisations' work manuals, so they could be communicated formally to all staff. Furthermore, working with central documents and information repositories within the organisations, altered the norms regarding formal and informal interactions and interrelationships. These manifested in terms of changes in how organisations' staff engage in work, how often and with whom within the organisation and project team they interact.

Figure 3. Analysis of BIM implementation constraints, their resolution and associated changes in work practices

When design workflows were altered, it also meant a shift in work intensity due to some tasks normally carried out later, now being done much earlier in the workflow. This would call for a re-conception of payment schedules/timelines for clients' agents, as explained by Informant Q11. Nevertheless, the participants could not readily and objectively articulate whether more work was typically done before BIM was adopted.

Changes in work routine are capable of voiding the significance and validity of organisational knowledge and process dynamics (Billett, 2009). They require mastery of new knowledge, competencies and processes by existing staff. According to the findings, new BIM 
management roles were created to bridge the knowledge gap. With the implementation of $\mathrm{BIM}$, professional work practices sometimes increase in complexity. This is due to the novelty of BIM processes and the conceptual knowledge required to put the tool(s) and processes into effective use. This complexity may with time, after work becomes routine, reduce and return to being routinised. The data, therefore, suggests that the ostensive and performative aspects work ro tines mutually einforcing Feldman and Pentland 2003).

Importantly, the creation of new BIM management roles or the expansion of existing staff roles, have impacted on leadership and authority structures. The selection of work team leaders tends towards technocracy, whereby selection of work team leaders is based on their superior knowledge of BIM technology and associated processes (Akintola et al., 2017). It is unclear, however, if this change within the organisation will be temporary or permanent with no reversion to old structures. Existing staff (before the introduction of BIM managers) who were previously not proficient or knowledgeable about BIM, may yet regain their positions in the organisation's structure. This is an important question to explore in future research endeavours, as investigated by Akintola et al. (2017) in the project team context.

BIM, both as a tool and process, inadvertently induces changes in the way professionals conceptualise and approach work within their respective organisations. For instance, BIM was described as a 'mind prosthetic' (Informant Q1) - an interesting choice of words. This suggests that the gap between idea conception in the mind and the physical action of design is now disappearing, and ideas that were previously too complex to model graphically are now coming to life in realistic form through BIM. Examining such BIM impacts using psycho-social theories is important, as this is one area in which more changes than expected may be happening. There is also the question of changing professional identity. For instance, a 
structural engineer may be wary of BIM's structural design and analytic capabilities, or a quantity surveyor of its quantification capabilities because it might take away, in part, that which is perceived as core professional identity-forming functions. Issues surrounding professional identity by themselves require in-depth analysis, although that is beyond the scope of the current work.

Nevertheless, some of the participants found it difficult to articulate in abundant detail, what they believe has changed in their organisations' work practices as a result of implementing BIM. This was overcome by posing case-based ex post facto questions, during which they could answer based on specific events that had taken place in the organisation.

Informant Q11 expressed the change impact of BIM within their organisation as follows, in response to a question on whether anything had hitherto changed:
Absolutely! ... But when I think about how it used to be, to what it is now, and how we've struggled... I think there are a lot of youngsters here in the company who just take a lot of that for granted because they've never had to work in any other kind of environment. So maybe they'll probably tell you no, nothing's changed ... [the changes are in] the way our teams are structured, [for example] you've got your central files so everyone's working in the same environment, working together in order to produce one building, and again I think a lot of it just became the norm.

The difficulty in clearly articulating work practice changes in detail by some of the participants, can be explained by work routinisation, whereby newly-created work practices (actions) become automatic (operations) after a number of repetitions (Kaptelinin and Nardi, 2006). 
These insights are instructive and at this point it is useful to revise the conceptual model, in accordance with the findings based on the actual experiences of the participants.

\section{Figure 4: Conceptual model (b)}

When contextualised within this study, a second version of the model was developed as in Figure 4, depicting how and why construction industry practices evolve when BIM tools as mediating artefacts are implemented within an existing activity from the organisational level to the team level. Expectedly, BIM prompts a new way of working and there are clear evidences of organisations and individual professionals coevolving with new technology and associated processes while new practices are being created. The data confirms the theory that dysfunctions create needs states within activity systems and that their resolution paves the way for change within organisational structures. Next, the question of the nature of change agency within this framework is explored.

\subsection{Theoretical re-description and analysis - distilling the agency of changes in work practices}

Although Kaptelinin and Nardi (2006) defined agency as the capacity and need to act, their narrower definition of the concept as the 'ability to produce an effect according to an intention' is apt in the following analysis; since an agent could be human or non-human, i.e., persons or things, even though they may manifest similar agencies (Kaptelinin and Nardi, 2006). Change in work practices may occur through anything or anyone that produces an effect without the intention to do so (conditional agency), based on human needs/intentions (need-based), produced by non-humans on behalf of a human (delegated) (Kaptelinin and Nardi, 2006), or as is evident in the data, a combination of these. For example, BIM authoring 
tool vendors inadvertently dictate and shape the way work is done in industries in which they enjoy near monopolies, but to which none of the software designers belong or share a stake in. Change agency in that sense is both conditional and delegated. It is within this framework that the findings were analysed further to understand the way changes in work practices came to happen.

The findings reveal that change does not necessarily have a direct link to the implementation of BIM. Regarding the means through which change occurs, the findings also indicate that these fall into the three types of change agency, as described above from the work of Kaptelinin and Nardi (2006). Without careful analysis, it is easy to assume that all changes in work practices that occur when BIM is implemented, can be construed only as either due to the tool(s) itself or through implementation by a human agent within the organisation. However, the changes reported by the participants in Table 4 and Figure 3 occur by the agency of an inseparable combination of delegated, conditional and need-based stimuli.

Delegated, conditional and need-based change agencies in this analysis lead from one to another, in that order. The argument is that BIM software tool developers by their design activity, dictate changes in the way work is done within the organisations that implement their products, even though they are not members of the organisation in which work practice patterns change. This is delegated agency (Kaptelinin and Nardi 2006), as in change impact produced through inanimate BIM tool(s) on behalf of the vendors, happens through the inherent prompting or dictation of how work may be done with BIM authoring software. Next changes produced as unintended impacts of implementing BIM constitute conditional agency, whereby, as argued from a theoretical perspective, constraints and their resolutions drive an 
evolution of work practices within the organisations (Engestrom, 2000; Kaptelinin and Nardi, 2006).

In this analysis, delegated, conditional and need-based change agency (as in Figure 5) are not mutually exclusive, as argued by Campbell et al.(2009), for other types of agency. In fact, while each may stimulate change independently, in this analysis, they also occur in a nested manner.

Figure 5. Dimensions of BIM-induced Change Agency

This analysis fits into the current theoretically-founded BIM discourse (Akintola et al., 2017, 2019; Çıdık et al., 2017; Dainty et al., 2017; Papadonikolaki et al., 2019; Poirier et al., 2017; Sherratt et al., 2020). It provides a new theoretical account of work practice change dynamics within professional consulting organisations when BIM is implemented. It also reveals the logic of actual change that has occurred, in addition to the nature of agency through which evolved work practices have emerged within the socio-cultural context.

Drawing from the above, we generate the final model in the iteration of the framework as shown in Figure 6, revealing the nature of change agency within the developing model of change in work practices and emphasising the role of BIM authoring/management tools' developers in stimulating change in the way work is done in the industry. This reinforces the suggestions of a subtle, unintended and often unnoticed technology push scenario, as proposed by Sherratt et al. (2020) and the earlier theoretical positions of Akintola et al. (2020).

Figure 6: Conceptual model (c) 
The data substantiates the subtle technology push through BIM tool developers as suggested in the literature, demonstrating the power that the construction industry seems to have handed to them, without intending to do so. This, however, does not come about without problems. Regarding its' influence on design for instance, informant Q3 states:

There's a whole plethora of issues and localisation problems...Then on the technology side, the challenge is...first and foremost is localisation. So if we talk Civils, the output from the BIM needs to conform to all industry standards, and it doesn't. All these things (existing design standards) have been around for a long time in the local market, we're not going to change what the authorities want to see, we have to adapt the BIM to suit and that's where we find we are meeting dead ends all the time...a lot of people would criticise the customisability of BIM software.

The construction industry continues to chase rapid technological advancements and often needs to change to suit the demands of the technology (or adapt it to suit), rather than develop the technology to fit a predesigned way of working. Implementing BIM 360 for instance could mean that, although it comes with some flexibility, the platform predetermines some of the construction team's collaboration workflows. Informant Q10 provides a pointer to a way forward as follows:

You've got to bridge the gap between the guy behind the computer and IT and the guy from industry...coming in there saying this and this is how the program should work.

This is a profound concern. Although developers like Autodesk actively seek the cooperation of industry and academia, it is yet unclear how much influence they have on the development process since the construction industry continues to chase the technology - although much to its' benefit. This begs the question - could this subtle power to change the way the industry functions ever develop an insidious dimension? As Sherratt et al. (2020) argue, the 
consequences could be significant if the industry continues to be pushed by technological advancements. The common-sense approach seems to be for construction professionals to get more involved at the application development stage, rather than play catchup. Thus, one could argue for more control of technological advancements and unintended change by industry professionals, but certainly not at the expense of slowing down its' pace.

\section{THEORETICAL IMPLICATIONS BIM-INDUCED CHANGES}

The recent critical discourse on BIM capabilities and impacts on the way organisations, project teams and indeed the construction industry functions, is reasonable and not unfounded. The critical direction the debates have taken, such as initiated by Fox (2014) and Dainty et al. (2017), is increasingly pertinent in the current times, and this study seeks to make an active contribution to these debates.

\subsection{Types of BIM-induced change and theoretical implications}

The theoretical assumptions suggested that change in work practices can be accounted for in the constraints experienced when BIM is implemented, the subsequent demands for change in existing ways of working and their eventual mitigation. The assumptions provided a conceptual basis and methodological direction on which to develop explanations for changes in work practices; as Cidik et al. (2017) aimed to do by using a different approach - although their work focussed on the project team context. Ideas from activity theory on agency (Kaptelinin \& Nardi 2006) were also employed to enable theoretical understandings of BIMinduced change using three types of agency: delegated, conditional and need-based change agencies. Therefore, the first contribution of the study was the combination and alignment of 
activity theory and aspects of agency theory to devise a unique conceptual framework for research and to explain change in work practices. Also, this framework, presented in the form of a conceptual model of expected change pattern, describes the important causal links to guide the rest of the study.

Furthermore, the initial model was refined and enriched in two subsequent iterations to account for empirical findings and emergent theoretical conceptualisations as the study developed. Essentially, the abductive approach adopted, enabled the identification of relevant themes in the emergent theory and the data and locating them in the conceptual framework graphically - linking evidence and social theory as can be seen in each iteration of the conceptual model. This advances the theoretical discourse with which this study engages. Indeed, that the two theoretical perspectives can be used in complement to describe the path, pattern (activity theory) and stimuli for change (agency theory), is a unique theoretical contribution. The final model also captures the relationship between human and non-human agents in the change process.

This study posits that BIM change impact can be distilled into that which is produced through delegated, conditional and need-based work practice change agency - although they remain entwined, as the production of change impact in one often leads to or involves another. Therefore, the findings and subsequent theorisation reveal that changing work practices occurs through a combination of all three types of agency. Without a doubt, most changes occur effectively by conscious need-based human action, except for those that are directly dictated by delegation through the BIM tool(s) itself. These findings are in agreement with Cidik et al.'s (2017) argument, that technologies impose or dictate certain aspects of work directly without the intervention of human agents. Also, the finding clearly answers some of 
the questions raised by Sherratt et al. (2020), confirming the subtle power unintentionally bestowed on BIM authoring/management tool developers, which could amount to influence to drive change more than that wielded by the construction industry professionals. While their influence is largely beneficial as can be seen in construction projects, could their influence also have an insidious dimension?

This paper thus presents a different perspective to the understanding of the oft repeated claim - 'BIM changes work practices' or that 'BIM requires changing work practices'. It contributes to answering the question of what changes and by what means. It bears mention that implementation of BIM in South Africa is not driven by any institutions per se, is without uniform standards and neither has it been widely adopted (Akintola et al., 2016; Froise and Shakantu, 2014). Change is, therefore, not driven by institutional agency - for example by government or other relevant authorities. A nuanced theoretical account of the dynamics of changes in work practices within professional organisations where BIM has been implemented has been developed.

\subsection{Practical implications}

Also, this study has advanced the discussion in the literature and theory from the general to the specific, and then back to a higher level of abstraction, thereby providing nuanced explanations of BIM-induced change. Without in-depth analysis, the nature of changes in professional work practices might be misconstrued as being solely due to the actions of human agents who actively partake in implementing BIM. Clearly, the influence of BIM in the construction industry is widespread. It is therefore important that professionals and researchers both understand and attempt to control delegated change. This is because, while 
there is collaboration between the construction industry and BIM authoring tool developers, there hasn't been enough emphasis on their almost unfettered capacity to drive change in the industry during the past two decades, even while they do not have a direct stake in the industry.

Construction industry professionals should endeavour to participate more in the development of technological innovation, rather than allow the technology to drive change and development in construction industry processes. With more technological innovations emerging - for example, blockchain and IoT applications in construction - construction professionals must get involved in the technical aspects of innovation development in order to be in control of the changes these technologies bring about in the industry. These results are also useful to help professional organisations make informed decisions, with in-depth understanding of the implications of implementing BIM at the outset.

\subsection{Limitations and future studies}

The data used for this study was drawn from purposefully selected cases, and so presents some limitations to the generalisability or transferability of the findings. However, the analysis has been abductive and backed by strong theoretical framing, in order to enable a generalisation of the findings to theory rather than attempt to generalise to a population (Patton, 2015). Furthermore, the findings were established through employing a rigorous methodology that involved analysis of negative evidence. For future research, there remain some other areas that still require attention, including the investigation of changing professional identity through technological innovation, since clearly BIM impacts on core identify forming functions of construction industry professionals. Secondly, the view of BIM 
as a mind prosthetic by designers is fascinating, and there may be value in studying what transpires in the minds of professionals when using BIM and its' impact on conceptual design processes.

\section{CONCLUSIONS}

The purpose of this study was to understand the change impacts on work practices when BIM is implemented by professional organisations. That is, how does change happen and what is the path and pattern of change? Also, we asked, by what means does change happen? This study provides explanation of the transformation of professional work practices, and thus engages with some of the recent questions raised, in the literature. The intention was to examine the types of changes that occur and appraise the types of agency responsible for the change. The findings suggest that the benefits of BIM are evident in the changes of organisational work practices with different types of agency responsible for creating the changes. BIM-induced changes may occur due to the direct agency of BIM tool implementation but also by delegated, conditional and needs-based agency. The study employed theoretical explanations and explored the occurrence of changes, and the nature of the agency and agents causing change and evolution of practices. BIM has proven to be disruptive to the traditional processes in the industry, but positively so. Like any other positively disruptive technological innovations, BIM is important to the growth of the construction industry. Professionals in the industry, importantly, need to get involved and participate in the initiation and the development of technological innovations that bring about change, rather than allow technology alone to drive changes in industry processes. We conclude that balanced BIM-induced changes should first be self-directed by the industry (need-based) even though changes produced through delegated, conditional work practice 
change agency are equally important and remain intertwined with the former.

\section{REFERENCES}

Ahn, Y.H., Kwak, Y.H. and Suk, S.J. (2016), “Contractors' Transformation Strategies for Adopting Building Information Modeling", Journal of Management in Engineering, Vol. 32 No. 1, available at:https://doi.org/10.1061/(ASCE)ME.1943-5479.0000390. Akintola, A., Douman, D., Kleynhans, M. and Maneli, S. (2016), "The Impact of Implementing BIM on AEC Organisational Workflows", Emerging Trends in Construction Organisational Practices and Project Management Knowledge Areas, presented at the 9th cidb Postgraduate Conference, Department of Construction Economics and Management, University of Cape Town, Cape Town, pp. 506-516.

Akintola, A., Venkatachalam, S. and Root, D. (2017), “New BIM Roles' Legitimacy, and Changing Power Dynamics on BIM-Enabled Projects", Journal of Construction Engineering and Management, Vol. 143 No. 9, pp. 1-11.

Akintola, A., Venkatachalam, S. and Root, D. (2020), “Understanding BIM's impact on professional work practices using activity theory", Construction Management and Economics, Routledge, Vol. 38 No. 5, pp. 447-467.

Arayici, Y., Egbu, C. and Coates, P. (2012), "Building Information Modelling Implementation and Remote Construction Projects: Issues, Challenges, and Critiques", Journal of Information Technology in Construction, Vol. XVI, pp. 75-79.

Atkinson, P. (1988), "Ethnomethodology: A Critical Review", Annual Review of Sociology, Vol. 14, pp. 441-465. 
Azzouz, A. and Papadonikolaki, E. (2020), “Boundary-spanning for managing digital innovation in the AEC sector", Architectural Engineering and Design Management, Taylor \& Francis, pp. 1-18.

Billett, S. (2009), “Changing work, work practice: The consequences for vocational education", International Handbook of Education for the Changing World of Work, pp. 175-187.

Blayse, A.M. and Manley, K. (2004), "Key influences on construction innovation", Construction Innovation, Vol. 4 No. 3, pp. 143-154.

Borg, R.F. (2005), “Discussion of 'Master Builder Project Delivery System and Designer Construction Knowledge' by J. K. Yates and Leslie C. Battersby", Journal of Construction Engineering \& Management, Vol. 131 No. 4, pp. 501-501.

Bowden, S. (2015), "Human and Nonhuman Agency in Deleuze”, in Roffe, J. and Stark, H. (Eds.), Deleuze and the Non/Human, Palgrave Macmillan UK, London, pp. 60-80. Campbell, K., Schwier, R.A. and Kenny, R.F. (2009), "The critical, relational practice of instructional design in higher education: an emerging model of change agency", Educational Technology Research and Development, Vol. 57 No. 5, pp. 645-663.

Cao, D., Wang, G., Li, H., Skitmore, M., Huang, T. and Zhang, W. (2015), “Practices and effectiveness of building information modelling in construction projects in China", Automation in Construction, Vol. 49, Part A No. 0, pp. 113-122.

Cidik, M.S., Boyd, D. and Thurairajah, N. (2014), “Understanding the polarized perspectives in BIM enabled projects", presented at the Proceedings 29th Annual Association of Researchers in Construction Management Conference, ARCOM 2013, pp. 703-713. 
Çıdık, M.S., Boyd, D. and Thurairajah, N. (2017), “Ordering in disguise: digital integration in built-environment practices", Building Research \& Information, Vol. 45 No. 6, pp. $665-680$.

Cosh, A., Fu, X. and Hughes, A. (2012), “Organisation structure and innovation performance in different environments", Small Business Economics, Springer Nature, Vol. 39 No. 2, pp. 301-317.

Crawford, K. and Hasan, H. (2006), "Demonstrations of the Activity Theory Framework for Resarch in Information Systems", Australasian Journal of Information Systems, Vol. 13 No. 2, pp. 49-67.

Creswell, J.W. (2013), Qualitative Inquiry and Research Design: Choosing among Five Approaches, Sage publications.

Crotty, R. (2012), The Impact of Building Information Modelling: Transforming Construction, Routledge.

Dainty, A., Leiringer, R., Fernie, S. and Harty, C. (2017), "BIM and the small construction firm: a critical perspective", Building Research \& Information, Vol. 45 No. 6, pp. 696-709.

Damanpour, F. (1991), “Organizational Innovation: A Meta-Analysis of Effects of Determinants and Moderators", Academy of Management Journal, Academy of Management, Vol. 34 No. 3, pp. 555-590.

Deutsch, R. (2011), BIM and Integrated Design: Strategies for Architectural Practice, John Wiley \& Sons, Inc., Hoboken, NJ.

Egan, J. (1998), Rethinking Construction, The Construction Task Force, London.

Engestrom, Y. (2000), “Activity Theory as a Framework for Analysing and Redesigning Work", Ergonomics, Vol. 43 No. 7, pp. 960-974. 
Engeström, Y. and Escalante, V. (1996), “Mundane tool or object of affection? The rise and fall of the postal buddy", Context and Consciousness: Activity Theory and HumanComputer Interaction, pp. 325-374.

Fan, S.L., Shen, Y.L. and Hung, T.W. (2013), "Study on building information modeling to construction disputes", Journal of the Chinese Institute of Civil and Hydraulic Engineering, Vol. 25 No. 3, pp. 257-264.

Feldman, M.S. and Pentland, B.T. (2003), “Reconceptualizing Organizational Routines as a Source of Flexibility and Change", Administrative Science Quarterly, [Sage Publications, Inc., Johnson Graduate School of Management, Cornell University], Vol. 48 No. 1, pp. 94-118.

Fletcher, A.J. (2017), “Applying critical realism in qualitative research: methodology meets method", International Journal of Social Research Methodology, Vol. 20 No. 2, pp. 181-194.

Fox, S. (2014), "Getting real about BIM: Critical realist descriptions as an alternative to the naïve framing and multiple fallacies of hype", International Journal of Managing Projects in Business, Vol. 7 No. 3, pp. 405-422.

Froise, T. and Shakantu, W. (2014), "Diffusion of innovations: an assessment of building information modelling uptake trends in South Africa", Journal of Construction Project Management and Innovation, Vol. 4 No. 2, pp. 895-911.

Geels, F.W. (2002), "Technological transitions as evolutionary reconfiguration processes: a multi-level perspective and a case-study", Research Policy, Vol. 31 No. 8, pp. 12571274. 
Gheisari, M. and Irizarry, J. (2016), "Investigating human and technological requirements for successful implementation of a BIM-based mobile augmented reality environment in facility management practices", Facilities, Vol. 34 No. 1-2, pp. 69-84.

Gu, N. and London, K. (2010), "Understanding and facilitating BIM adoption in the AEC industry", Automation in Construction, Vol. 19 No. 8, pp. 988-999.

Harris, V. (2016), South African BIM Survey Report 2016, South African BIM Institute.

Hartmann, T., van Meerveld, H., Vossebeld, N. and Adriaanse, A. (2012), “Aligning building information model tools and construction management methods", Automation in Construction, Vol. 22 No. 0, pp. 605-613.

Herr, C.M. and Fischer, T. (2019), "BIM adoption across the Chinese AEC industries: An extended BIM adoption model", Journal of Computational Design and Engineering, Vol. 6 No. 2, pp. 173-178.

Howard, H., Levitt, R., Paulson, B., Pohl, J. and Tatum, C. (1989), “Computer Integration: Reducing Fragmentation in AEC Industry", Journal of Computing in Civil Engineering, Vol. 3 No. 1, pp. 18-32.

Jung, Y. and Joo, M. (2011), “Building information modelling (BIM) framework for practical implementation", Automation in Construction, Vol. 20 No. 2, pp. 126-133.

Kaptelinin, V. and Nardi, B. (2006), Acting With Technology: Activity Theory and Interaction Design, The MIT Press, Massachusetts.

Kuutti, K. (1999), "Activity theory, transformation of work, and information systems design", Perspectives on Activity Theory, Cambridge University Press, New York, pp. 360-376.

Latham, M. (1994), Constructing the Team.

Leicht, K.T. and Fennell, M.L. (1997), "The Changing of Organizational Context of Professional Work", Annual Review of Sociology, Annual Reviews Inc., Vol. 23, p. 215. 
Love, P., Edwards, D., Han, S. and Goh, Y. (2011), “Design error reduction: toward the effective utilization of building information modeling", Research in Engineering Design, Vol. 22 No. 3, pp. 173-187.

Marshall, M.N. (1996), "The key informant technique”, Family Practice, Vol. 13 No. 1, pp. 92-97.

Miles, M.B., Huberman, A.M. and Saldaña, J. (2014), Qualitative Data Analysis: A Methods Sourcebook, SAGE Publications, Incorporated.

Morrissey, B. (2003), When Women Kill: Questions of Agency and Subjectivity, Routledge, London.

Nawi, M.N.M., Lee, A., Azman, M.N.A. and Kamar, K.A.M. (2013), “Fragmentation Issue in Malaysian Industrialised Building System (IBS) Projects", Journal of Engineering Science and Technology, Vol. 8 No. 3, pp. 278-292.

Oraee, M., Hosseini, M.R., Edwards, D.J., Li, H., Papadonikolaki, E. and Cao, D. (2019), "Collaboration barriers in BIM-based construction networks: A conceptual model", International Journal of Project Management, Vol. 37 No. 6, pp. 839-854.

Papadonikolaki, E., van Oel, C. and Kagioglou, M. (2019), “Organising and Managing boundaries: A structurational view of collaboration with Building Information Modelling (BIM)", International Journal of Project Management, Elsevier, Vol. 37 No. 3, pp. 378-394.

Papadonikolaki, E. and Wamelink, H. (2017), “Inter- and intra-organizational conditions for supply chain integration with BIM", Building Research \& Information, Vol. 45 No. 6, pp. 649-664.

Patton, M.Q. (2015), Qualitative Research \& Evaluation Methods: Integrating Theory and Practice, SAGE Publications. 
Poirier, E.A., Forgues, D. and Staub-French, S. (2017), "Understanding the impact of BIM on collaboration: a Canadian case study", Building Research \& Information, Vol. 45 No. 6, pp. 681-695.

Porwal, A. and Hewage, K.N. (2013), "Building Information Modeling (BIM) partnering framework for public construction projects", Automation in Construction, Vol. 31, pp. 204-214.

Ravitch, S. and Riggan, M. (2012), Reason \& Rigor: How Conceptual Frameworks Guide Research, SAGE Publications.

Rekola, M., Kojima, J. and Mäkeläinen, T. (2010), "Towards Integrated Design and Delivery Solutions: Pinpointed Challenges of Process Change", Architectural Engineering \& Design Management, Vol. 6 No. S1, pp. 264-278.

Rezgui, Y., Beach, T. and Rana, O. (2013), “A governance approach for BIM management across lifecycle and supply chains using mixed-modes of information delivery", Journal of Civil Engineering and Management, Vol. 19 No. 2, pp. 239-258.

Rogers, J., Chong, H.-Y. and Preece, C. (2015), "Adoption of Building Information Modelling technology (BIM): Perspectives from Malaysian engineering consulting services firms", Engineering, Construction and Architectural Management, Vol. 22 No. 4, pp. 424-445.

Sackey, E. and Akotia, J. (2017), "Spanning the multilevel boundaries of construction organisations: Towards the delivery of BIM-compliant projects", Construction Innovation, Vol. 17 No. 3, pp. 273-293.

Sæther, B. (1998), "Retroduction: an alternative research strategy?", Business Strategy and the Environment, Vol. 7 No. 4, pp. 245-249. 
Sebastian, R. (2011), "Changing Roles of the Clients, Architects and Contractors through BIM", Engineering, Construction and Architectural Management, Vol. XVIII No. 2, pp. 176-187.

Sherratt, F., Dowsett, R. and Sherratt, S. (2020), "Construction 4.0 and Its Potential Impact on People Working in the Construction Industry", Proceedings of the Institution of Civil Engineers-Management, Procurement and Law, Thomas Telford Ltd, pp. 1-8.

Succar, B. (2009), "Building information modelling framework: A research and delivery foundation for industry stakeholders", Automation in Construction, Vol. 18 No. 3, pp. 357-375.

Succar, B. and Kassem, M. (2015), "Macro-BIM adoption: Conceptual structures", Automation in Construction, Vol. 57, pp. 64-79.

Suchan, J. (2006), “Changing organizational communication practices and norms: A framework", Journal of Business and Technical Communication, Sage Publications Sage CA: Thousand Oaks, CA, Vol. 20 No. 1, pp. 5-47.

Suermann, P.C. and Issa, R.R.A. (2009), “Dynamic prototyping: The united states air force building information modeling initiative", Vol. 346, presented at the Proceedings of the 2009 ASCE International Workshop on Computing in Civil Engineering, pp. 485494.

Taylor, J.E. and Bernstein, P.G. (2009), "Paradigm trajectories of building information modeling practice in project networks", Journal of Management in Engineering, Vol. 25 No. 2, pp. 69-76.

Tremblay, M.-A. (1957), "The key informant technique: A nonethnographic application", American Anthropologist, Vol. 59 No. 4, pp. 688-701.

Urquhart, C. (2013), Grounded Theory for Qualitative Research: A Practical Guide, Sage. 
Vidalakis, C., Abanda, F.H. and Oti, A.H. (2019), "BIM adoption and implementation: focusing on SMEs", Construction Innovation.

Walker, D.H. (2016), "Reflecting on 10 years of focus on innovation, organisational learning and knowledge management literature in a construction project management context", Construction Innovation, Vol. 16 No. 2, pp. 114-126.

Wengraf, T. (2001), Qualitative Research Interviewing, SAGE Publications Ltd.

$\mathrm{Xu}, \mathrm{H} ., \mathrm{Feng}$, J. and Li, S. (2014), "Users-orientated evaluation of building information model in the Chinese construction industry", Automation in Construction, Vol. 39, pp. 3246.

Yalcinkaya, M. and Singh, V. (2015), "Patterns and trends in Building Information Modeling (BIM) research: A Latent Semantic Analysis", Automation in Construction, Vol. 59, pp. $68-80$.

Yamagata-Lynch, L.C. (2010), Activity Systems Analysis Methods: Understanding Complex Learning Environments, Springer.

Yin, R. (2014), Case Study Research: Design and Methods, 5th edition., SAGE Publications, United Kingdom.

Yin, R.K. (2016), Qualitative Research From Start to Finish, Second Edition, Vol. Second edition, The Guilford Press, New York, available at: https://oxfordbrookes.idm.oclc.org/login?url=http://search.ebscohost.com/login.as px?direct=true $\& d b=$ nlebk $\& A N=1017588 \&$ site $=$ ehost-live.

Yuan, H. and Yang, Y. (2019), “BIM Adoption under Government Subsidy: Technology Diffusion Perspective", Journal of Construction Engineering and Management, Vol. 146 No. 1, p. 04019089. 
Figure 1. Conceptual model (a) 


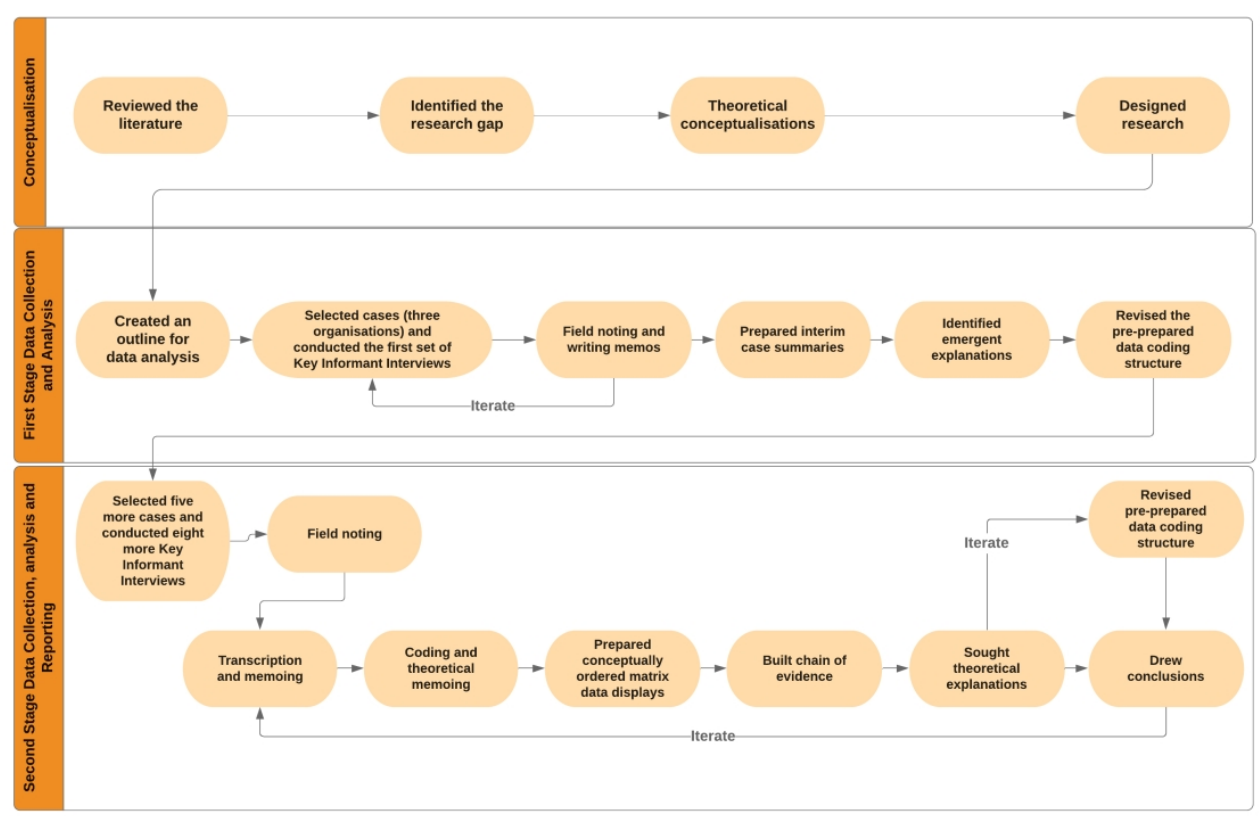

Figure 2. Research framework 
Figure 3. Analysis of BIM implementation constraints, their resolution and associated changes in work practices
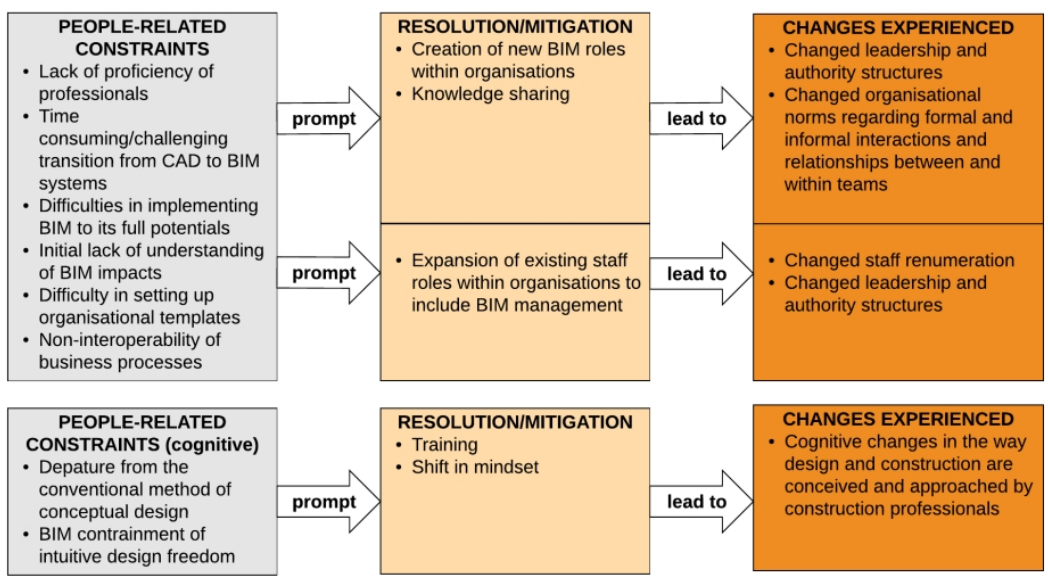
Figure 4. Conceptual model (b) 


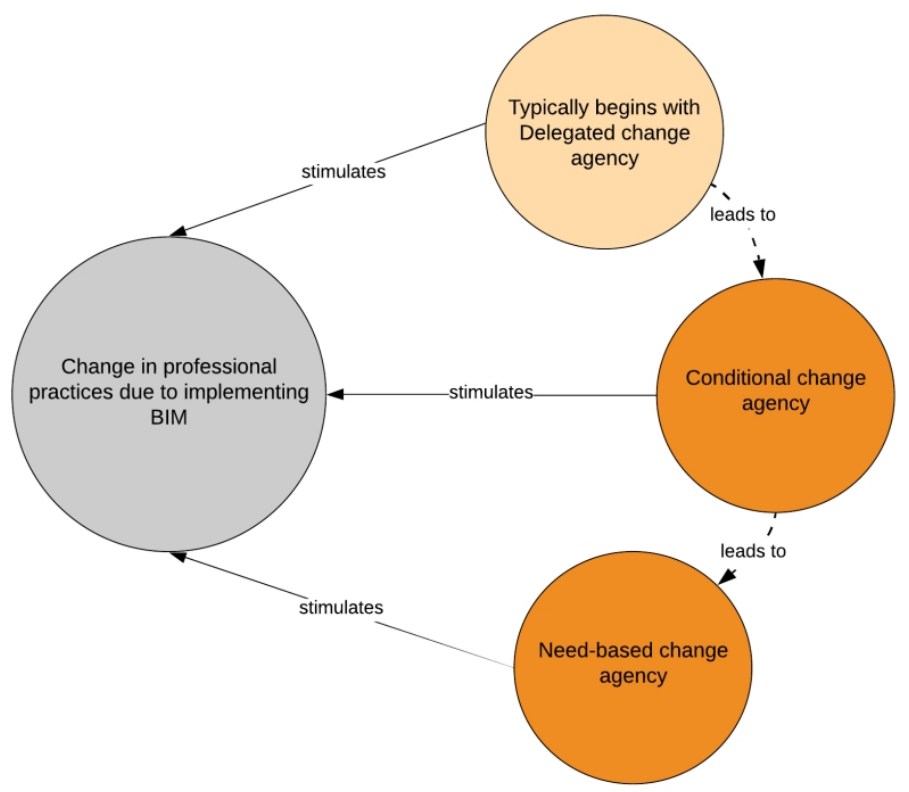

Figure 5. Dimensions of BIM-induced Change Agency 


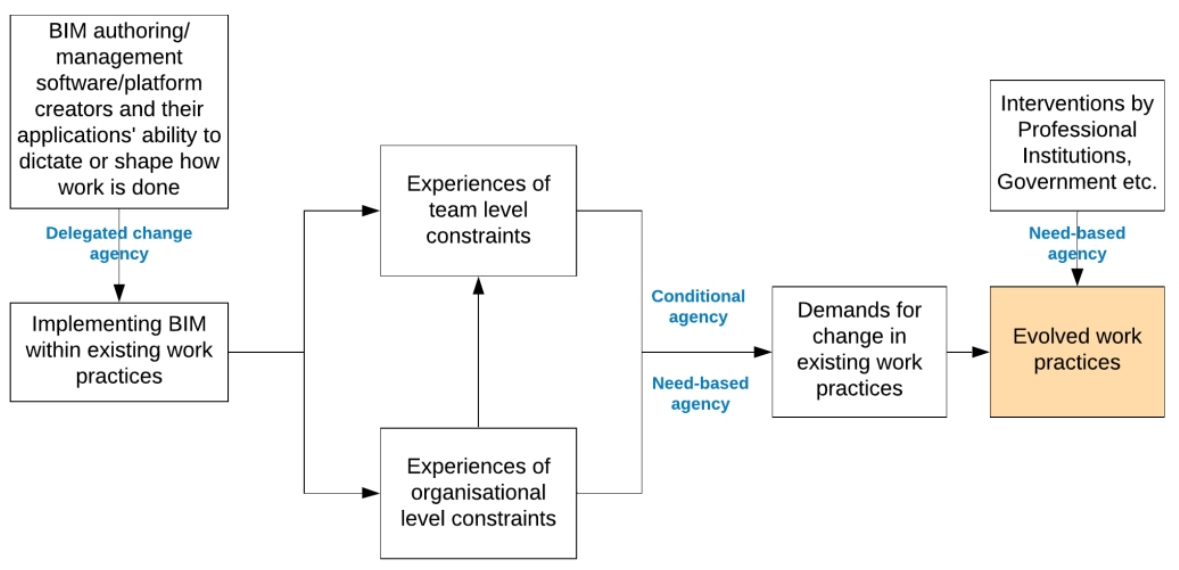

Figure 6. Conceptual model (c) 
Table 1. Research methodologies of similar studies

\begin{tabular}{|c|c|c|c|c|}
\hline AUTHOR(S) & ISSUE STUDIED & $\begin{array}{l}\text { NATURE OF } \\
\text { RESEARCH AND } \\
\text { CONTRIBUTIONS }\end{array}$ & METHOD & FOCUS \\
\hline Fox (2014) & $\begin{array}{l}\text { Critical realist descriptions } \\
\text { of BIM induced change }\end{array}$ & $\begin{array}{l}\text { Conceptual/ } \\
\text { theoretical and } \\
\text { practical }\end{array}$ & $\begin{array}{l}\text { Case of one } \\
\text { organisation (four } \\
\text { interviews) }\end{array}$ & $\begin{array}{l}\text { Focus on professional } \\
\text { work practice rather } \\
\text { than the broader } \\
\text { organisation work } \\
\text { perspective }\end{array}$ \\
\hline $\begin{array}{l}\text { Dainty et al. } \\
(2017)\end{array}$ & $\begin{array}{l}\text { A critical perspective on } \\
\text { BIM and the small } \\
\text { construction firm }\end{array}$ & $\begin{array}{l}\text { Conceptual/ } \\
\text { theoretical }\end{array}$ & No empirical work & $\begin{array}{l}\text { Focus on professional } \\
\text { work, organisations } \\
\text { and the industry }\end{array}$ \\
\hline $\begin{array}{l}\text { Papadonikolaki } \\
\text { and Wamelink } \\
(2017)\end{array}$ & $\begin{array}{l}\text { Inter- and intra- } \\
\text { organizational conditions } \\
\text { for supply chain } \\
\text { integration with BIM }\end{array}$ & $\begin{array}{l}\text { Conceptual/ } \\
\text { theoretical and } \\
\text { practical }\end{array}$ & $\begin{array}{l}\text { Two BIM-based } \\
\text { project cases } \\
\text { (fourteen Interviews) }\end{array}$ & $\begin{array}{l}\text { Network-based } \\
\text { perspective rather } \\
\text { than from a 'focal' } \\
\text { firm perspective to } \\
\text { study intra- \& } \\
\text { interorganizational } \\
\text { relationships }\end{array}$ \\
\hline $\begin{array}{l}\text { Çıdık et al. } \\
\text { (2017) }\end{array}$ & $\begin{array}{l}\text { Exposing the practice- } \\
\text { level phenomenon } \\
\text { responsible for the } \\
\text { ongoing change to } \\
\text { develop a critical } \\
\text { understanding and enable } \\
\text { better interventions }\end{array}$ & $\begin{array}{l}\text { Conceptual/ } \\
\text { theoretical and } \\
\text { empirical }\end{array}$ & $\begin{array}{l}\text { Passive observations } \\
\text { of } 23 \text { project } \\
\text { meetings and four } \\
\text { semi- structured } \\
\text { interviews }\end{array}$ & $\begin{array}{l}\text { Practice based } \\
\text { approach. The view of } \\
\text { change from the } \\
\text { practitioner's lens. }\end{array}$ \\
\hline $\begin{array}{l}\text { Sherratt et al. } \\
(2020)\end{array}$ & $\begin{array}{l}\text { Construction } 4.0 \text { and its } \\
\text { potential impact on } \\
\text { people working in the } \\
\text { construction industry }\end{array}$ & $\begin{array}{l}\text { Conceptual/ } \\
\text { theoretical }\end{array}$ & No empirical work & $\begin{array}{l}\text { Focus on professional } \\
\text { work, organisations } \\
\text { and the industry }\end{array}$ \\
\hline Current study & $\begin{array}{l}\text { Understanding the nature } \\
\text { and stimuli for BIM- } \\
\text { induced change in work } \\
\text { practices and their } \\
\text { implications }\end{array}$ & $\begin{array}{l}\text { Conceptual/ } \\
\text { theoretical and } \\
\text { empirical }\end{array}$ & $\begin{array}{l}\text { Eight cases of } \\
\text { organisations from } \\
\text { which eleven key } \\
\text { informant semi- } \\
\text { structured interviews } \\
\text { with professionals } \\
\text { about their } \\
\text { experiences of BIM } \\
\text { implementation were } \\
\text { conducted. }\end{array}$ & $\begin{array}{l}\text { Practice based } \\
\text { approach. The view of } \\
\text { change from the } \\
\text { practitioner's lens. } \\
\text { Also, there is a Focus } \\
\text { on professional work } \\
\text { practice rather than } \\
\text { the broader } \\
\text { organisation work } \\
\text { perspective. }\end{array}$ \\
\hline
\end{tabular}




\begin{tabular}{|c|c|c|}
\hline CASES (ORG) & PARTICIPANT & PROFILE \\
\hline ORG1 & $\begin{array}{l}\text { Q2: ARCHITECT \& BIM } \\
\text { COORDINATOR }\end{array}$ & $\begin{array}{l}\text { The participant is a professional architect who was employed } \\
\text { about three years ago with BIM expertise as a key criterion. } \\
\text { Since joining the organisation, the participant has, in } \\
\text { conjunction with colleagues, helped in formalising BIM } \\
\text { adoption companywide. (It is a multidisciplinary organisation } \\
\text { with multinational operations and its parent company is located } \\
\text { in a Western country.) }\end{array}$ \\
\hline ORG2 & $\begin{array}{l}\text { Q3: CIVIL/ } \\
\text { STRUCTURAL } \\
\text { ENGINEER, VDC/BIM } \\
\text { COORDINATOR, \& } \\
\text { DIRECTOR }\end{array}$ & $\begin{array}{l}\text { The participant is a regional director within the organisation (a } \\
\text { multidisciplinary organisation with multinational scope of } \\
\text { operations and with a parent company in a developed country), } \\
\text { with responsibility and experience in facilitating Virtual Design } \\
\text { and Construction (VDC) sessions and BIM within the } \\
\text { organisation. The organisation has taken on a decidedly formal } \\
\text { approach to BIM implementation, by borrowing from } \\
\text { exemplary implementation cases in company branches in } \\
\text { countries like the UK. }\end{array}$ \\
\hline ORG3 & $\begin{array}{l}\text { Q11: ARCHITECT \& BIM } \\
\text { COORDINATOR }\end{array}$ & $\begin{array}{l}\text { The participant has had experience in using BIM authoring tools } \\
\text { for about } 12 \text { years, while the organisation (an architectural } \\
\text { organisation with multinational scope of operations) has been } \\
\text { using BIM authoring software for about a decade as one of the } \\
\text { early adopters in the country. BIM experience was one of the } \\
\text { key criteria for which the participant was employed. Further, } \\
\text { Q11 has been at the forefront of developing a formal } \\
\text { companywide approach to BIM implementation within the } \\
\text { organisation with the express support of top management. }\end{array}$ \\
\hline \multirow{2}{*}{ ORG4 } & $\begin{array}{l}\text { Q4: ARCHITECT, } \\
\text { PROJECT MANAGER, \& } \\
\text { VDC/BIM } \\
\text { COORDINATOR }\end{array}$ & $\begin{array}{l}\text { The participant is responsible for facilitating both BIM and VDC } \\
\text { (virtual design and construction) coordination within the } \\
\text { organisation (multidisciplinary and multinational scope of } \\
\text { operations) and on multi-organisational projects. The } \\
\text { participant, therefore, provided valuable insight and broad } \\
\text { perspectives about implementing BIM. }\end{array}$ \\
\hline & $\begin{array}{l}\text { Q7: BIM MANAGER \& } \\
\text { ARCHITECT }\end{array}$ & $\begin{array}{l}\text { Q7 was employed specifically to facilitate implementation of } \\
\text { BIM by the organisation countrywide (a multidisciplinary } \\
\text { organisation with multinational scope of operations and } \\
\text { providing mainly engineering services) to match the global drive } \\
\text { of the organisation to make BIM a key strategy for delivering on } \\
\text { clients' demands using their international branches as } \\
\text { exemplars. }\end{array}$ \\
\hline \multirow[t]{2}{*}{ ORG5 } & Q1: BIM MANAGER & $\begin{array}{l}\text { The participant was employed about five years ago by the } \\
\text { organisation (an architectural organisation with multinational } \\
\text { operations), in a dedicated role to manage the day-to-day } \\
\text { development of BIM and BIM content within the organisation, } \\
\text { while also helping to keep the organisation abreast of BIM } \\
\text { development internationally. }\end{array}$ \\
\hline & $\begin{array}{l}\text { Q9: ARCHITECT \& } \\
\text { DIRECTOR }\end{array}$ & $\begin{array}{l}\text { Q9 is a professional architect and director of the organisation } \\
\text { (an architectural organisation with multinational scope of } \\
\text { operations). Having been using BIM authoring software for } \\
\text { about eight years, the participant gained extensive experience } \\
\text { which enabled broad insights, often from a managerial } \\
\text { perspective. }\end{array}$ \\
\hline
\end{tabular}




\begin{tabular}{|c|c|c|}
\hline ORG6 & $\begin{array}{l}\text { Q10: } \\
\text { CIVIL/STRUCTURAL } \\
\text { ENGINEER \& DIRECTOR }\end{array}$ & $\begin{array}{l}\text { Q10 is a director with Civil/Structural Engineering } \\
\text { qualifications. The organisation (a multidisciplinary } \\
\text { organisation with multinational scope of operations) had } \\
\text { decided on implementing BIM as a formal strategy for } \\
\text { delivering on projects about two and a half years before the } \\
\text { interview. However, due to severe difficulties encountered, it } \\
\text { decided to return to using CAD tools by January } 2016 \text { (see also } \\
\text { Q5_Architect). }\end{array}$ \\
\hline ORG6 & Q5: ARCHITECT & $\begin{array}{l}\text { This participant, although knowledgeable about issues around } \\
\text { BIM and its implementation having been a user, joined the } \\
\text { organisation (multidisciplinary and multinational scope of } \\
\text { operations) shortly before they decided to discontinue BIM use } \\
\text { by January } 2016 \text { (by January } 2016 \text { the organisation had gone } \\
\text { back to using CAD for all projects). }\end{array}$ \\
\hline OGR7 & Q8: ARCHITECT & $\begin{array}{l}\text { Q8 is a professional architect at an architectural organisation } \\
\text { with only local operations. However, the organisation had } \\
\text { decided to take the BIM route to delivering projects recently. } \\
\text { Being a relatively small-sized organisation compared to the rest, } \\
\text { it had not taken any formal approach to adopting BIM. }\end{array}$ \\
\hline ORG8 & $\begin{array}{l}\text { Q6: BIM MANAGER \& } \\
\text { ARCHITECT }\end{array}$ & $\begin{array}{l}\text { Q6 was a Senior Architectural Technologist who also had } \\
\text { extensive experience working for a BIM consulting firm in South } \\
\text { Africa, from where experience was gained in setting up BIM } \\
\text { within organisations and coordinating BIM on multidisciplinary } \\
\text { and multi-organisational projects. The participant had only } \\
\text { recently joined the current organisation (architectural) to help } \\
\text { facilitate on job skills development around BIM and } \\
\text { development of uniform organisational process and design } \\
\text { templates. For these reasons, the participant provided very } \\
\text { enlightening and unique perspectives. }\end{array}$ \\
\hline
\end{tabular}


1 Table 3. BIM adoption properties

\begin{tabular}{|c|c|c|c|}
\hline ORGANISATIONS & ADOPTION YEAR & MOTIVES FOR ADOPTION & ADOPTION STRATEGY \\
\hline $\begin{array}{l}\text { Organisation } 1 \text { (ORG1) } \\
\text { (Informant Q2) }\end{array}$ & $\begin{array}{l}\text { - About } 2.5 \text { years prior as a } \\
\text { formalised way of } \\
\text { delivering projects }\end{array}$ & $\begin{array}{l}\text { - The expected benefits and advantages } \\
\text { - Adopted as a company value } \\
\text { - It is a strategy and key method for providing services } \\
\text { - Flows naturally from the architectural practice to other } \\
\text { disciplines }\end{array}$ & $\begin{array}{l}\text { - Formalised adoption system } \\
\text { within organisation } \\
\text { - BIM management position } \\
\text { created in-house }\end{array}$ \\
\hline $\begin{array}{l}\text { Organisation } 2 \text { (ORG 2) } \\
\text { (Informant Q3) }\end{array}$ & $\begin{array}{l}\text { - About } 10 \text { years prior as a } \\
\text { formalised way of } \\
\text { delivering projects }\end{array}$ & $\begin{array}{l}\text { - It is the company's culture to lead rather than follow } \\
\text { - Mandated by senior leadership as a pillar of group strategy for } \\
\text { delivering projects, and is being pushed and driven throughout } \\
\text { the business } \\
\text { - It provides competitive advantage } \\
\text { - It is a means for reducing organisational costs }\end{array}$ & $\begin{array}{l}\text { - Formalised adoption system } \\
\text { within organisation } \\
\text { - BIM management position } \\
\text { created in-house }\end{array}$ \\
\hline $\begin{array}{l}\text { Organisation } 3 \text { (ORG 3) } \\
\text { (Informant Q11) }\end{array}$ & $\begin{array}{l}\text { - About } 10 \text { years prior as a } \\
\text { formalised way of } \\
\text { working within the } \\
\text { organisation }\end{array}$ & $\begin{array}{l}\text { - The expected benefits and advantages } \\
\text { - A way to streamline organisational processes to reduce team } \\
\text { sizes, and deliver information more efficiently } \\
\text { - Driven by organisation's director's foresight and leadership } \\
\text { - It made commercial sense to the leadership to go the BIM route }\end{array}$ & $\begin{array}{l}\text { - Formalised adoption system } \\
\text { within organisation } \\
\text { - BIM management position } \\
\text { created in-house }\end{array}$ \\
\hline $\begin{array}{l}\text { Organisation } 4 \text { (ORG 4) } \\
\text { (Informants Q4 and Q7) }\end{array}$ & $\begin{array}{l}\text { - About } 2.5 \text { years prior as a } \\
\text { formalised way of } \\
\text { working within the } \\
\text { organisation }\end{array}$ & $\begin{array}{l}\text { - As a strategy and key method providing services } \\
\text { - The expected benefits and advantages } \\
\text { - It was seen as capable of helping with the challenging } \\
\text { construction market } \\
\text { - Helped to meet increasing client demands to push down on fees }\end{array}$ & $\begin{array}{l}\text { - Formalised adoption system } \\
\text { within organisation } \\
\text { - BIM management position } \\
\text { created in-house }\end{array}$ \\
\hline $\begin{array}{l}\text { Organisation } 5 \text { (ORG 5) } \\
\text { (Informants Q1 and Q9) }\end{array}$ & $\begin{array}{l}\text { - About } 8 \text { years prior } \\
\text { within the organisation } \\
\text { but not formally }\end{array}$ & $\begin{array}{l}\text { - Perceived to be the next level of development } \\
\text { - To provide better quality information on projects }\end{array}$ & $\begin{array}{l}\text { - No formal organisation plan to } \\
\text { implement } \\
\text { - No BIM management position } \\
\text { created in-house }\end{array}$ \\
\hline $\begin{array}{l}\text { Organisation } 6 \text { (ORG 6) } \\
\text { (Informants Q5 and Q10) }\end{array}$ & $\begin{array}{l}\text { - About } 2.5 \text { years prior } \\
\text { within the organisation } \\
\text { but not formally }\end{array}$ & - Expected benefits, particularly increased productivity & $\begin{array}{l}\text { - No formal organisation plan to } \\
\text { implement } \\
\text { - No BIM management position } \\
\text { created in-house }\end{array}$ \\
\hline
\end{tabular}




\begin{tabular}{|c|c|c|c|}
\hline ORGANISATIONS & ADOPTION YEAR & MOTIVES FOR ADOPTION & ADOPTION STRATEGY \\
\hline $\begin{array}{l}\text { Organisation 7* (ORG 7) } \\
\text { (Informant Q8) }\end{array}$ & $\begin{array}{l}\text { - About } 2 \text { years prior } \\
\text { within the organisation } \\
\text { but not formally }\end{array}$ & - The expected benefits and advantages & $\begin{array}{l}\text { - No formal organisation plan to } \\
\text { implement } \\
\text { - No BIM management position } \\
\text { created in-house }\end{array}$ \\
\hline $\begin{array}{l}\text { Organisation } 8 \text { (ORG 8) } \\
\text { (Informant Q6) }\end{array}$ & $\begin{array}{l}\text { Less than a year as a } \\
\text { formal way of working } \\
\text { within the organisation } \\
\text { (Participant has had } \\
\text { several years of } \\
\text { experience prior to } \\
\text { joining the organisation) }\end{array}$ & $\begin{array}{l}\text { - Helps in meeting increasing client demands for discounts } \\
\text { - Expected benefits and advantages } \\
\text { - Response to the industry shift to BIM }\end{array}$ & $\begin{array}{l}\text { - In the process of creating a } \\
\text { formal adoption and } \\
\text { implementation plan for the } \\
\text { organisation } \\
\text { - No BIM management position } \\
\text { created in-house }\end{array}$ \\
\hline
\end{tabular}

*All except this organisation were active international 
Table 3. Experiences of change within organisations and teams

\begin{tabular}{|c|c|c|c|c|}
\hline \multirow{2}{*}{ PARTICIPANTS } & \multicolumn{2}{|c|}{ PROCEDURAL CHANGES } & \multicolumn{2}{|c|}{ SOCIAL-CULTURAL CHANGES } \\
\hline & WITHIN ORGANISATIONS & WITHIN TEAMS & WITHIN ORGANISATIONS & WITHIN TEAMS \\
\hline $\begin{array}{l}\text { Q1: BIM } \\
\text { MANAGER }\end{array}$ & $\begin{array}{l}\text { A completely different design } \\
\text { workflow was required to implement } \\
\text { BIM }\end{array}$ & $\begin{array}{l}\text { Certain tasks are carried out } \\
\text { earlier in the delivery process }\end{array}$ & $\begin{array}{l}\text { - Change in organisational mind-set } \\
\text { to suit a completely different } \\
\text { design workflow } \\
\text { - The creation of the BIM manager } \\
\text { role which also alters organisation } \\
\text { structure }\end{array}$ & - $\mathrm{n} / \mathrm{a}$ \\
\hline $\begin{array}{l}\text { Q2: ARCHITECT \& } \\
\text { BIM } \\
\text { COORDINATOR }\end{array}$ & $\begin{array}{l}\text { BIM streamlined the design process } \\
\text { - BIM drove a different process/system } \\
\text { for design quality management, } \\
\text { design development and design } \\
\text { progress monitoring }\end{array}$ & $\begin{array}{l}\text { Sequence of design tasks in the } \\
\text { delivery process was altered. } \\
\text { Certain building elements were } \\
\text { designed earlier than usual } \\
\text { - } \quad \text { Design operations are different } \\
\text { - The flow of information is different } \\
\text { - Certain design functions run } \\
\text { concurrently } \\
\text { A lot more coordination was } \\
\text { required from the services } \\
\text { engineers } \\
\text { The coordinating process has } \\
\text { evolved }\end{array}$ & $\begin{array}{l}\text { - The appointment of a BIM manager } \\
\text { and coordinator impacts on } \\
\text { organisational interrelationships } \\
\text { - Individual roles have expanded } \\
\text { along with expanded job } \\
\text { descriptions }\end{array}$ & $\begin{array}{l}\text { - The design role has only evolved } \\
\text { in terms of how work was done }\end{array}$ \\
\hline
\end{tabular}




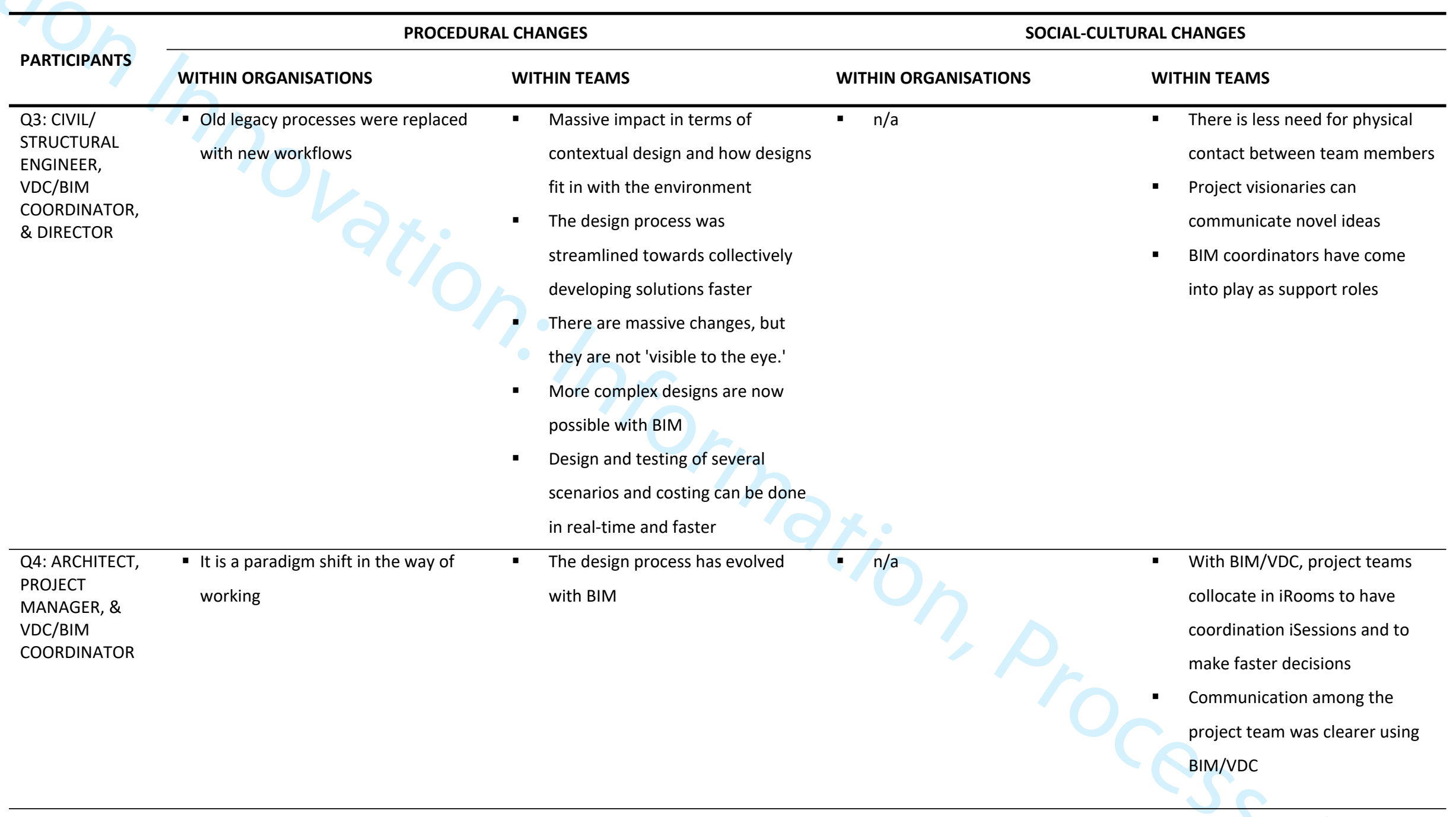




\begin{tabular}{|c|c|c|c|c|}
\hline \multirow{2}{*}{ PARTICIPANTS } & \multicolumn{2}{|c|}{ PROCEDURAL CHANGES } & \multicolumn{2}{|c|}{ SOCIAL-CULTURAL CHANGES } \\
\hline & WITHIN ORGANISATIONS & WITHIN TEAMS & WITHIN ORGANISATIONS & WITHIN TEAMS \\
\hline Q5: ARCHITECT & $\begin{array}{l}\text { - Getting the end result of design was } \\
\text { done in a "roundabout way" rather } \\
\text { than a direct way } \\
\text { - Modelling in BIM reorders the } \\
\text { sequence for designing building } \\
\text { elements } \\
\text { - The design process was sped up by } \\
\text { modelling in BIM } \\
\text { - BIM required entirely new } \\
\text { organisational work processes }\end{array}$ & n/a & $\begin{array}{l}\text { BIM influenced expectations from } \\
\text { clients of project deliverables }\end{array}$ & $\begin{array}{l}\text { Fee scale structure needs to } \\
\text { evolve with new demands** }\end{array}$ \\
\hline $\begin{array}{l}\text { Q6: BIM } \\
\text { MANAGER \& } \\
\text { ARCHITECT }\end{array}$ & $\begin{array}{l}\text { - BIM drove a completely different } \\
\text { process compared to CAD } \\
\text { - Designing in BIM shortens the time } \\
\text { required to produce outcomes }\end{array}$ & - $\mathrm{n} / \mathrm{a}$ & $\begin{array}{l}\text { - A BIM manager/coordinator's role } \\
\text { impacts on the line of authority and } \\
\text { leadership within the firm ("If it's in } \\
\text { a company, you are sitting one } \\
\text { below the director, because you do } \\
\text { need to call people to task") } \\
\text { - The appointment of a BIM manager } \\
\text { and coordinator (impacts on } \\
\text { organisational relationships) } \\
\text { - Individual roles have also expanded } \\
\text { with expanded job descriptions }\end{array}$ & $\begin{array}{l}\text { - Lines of communication and } \\
\text { interaction were altered because } \\
\text { BIM managers level of leadership } \\
\text { is very close to that of an } \\
\text { Architect, if not second to the } \\
\text { architect }\end{array}$ \\
\hline
\end{tabular}




\begin{tabular}{|c|c|c|c|c|}
\hline \multirow{2}{*}{ PARTICIPANTS } & \multicolumn{2}{|c|}{ PROCEDURAL CHANGES } & \multicolumn{2}{|c|}{ SOCIAL-CULTURAL CHANGES } \\
\hline & WITHIN ORGANISATIONS & WITHIN TEAMS & WITHIN ORGANISATIONS & WITHIN TEAMS \\
\hline $\begin{array}{l}\text { Q7: BIM } \\
\text { MANAGER \& } \\
\text { ARCHITECT }\end{array}$ & $\begin{array}{l}\text { - Changed workflows } \\
\text { - Requires the modification } \\
\text { organisational practice manuals }\end{array}$ & $\begin{array}{l}\text { - The delivery process has evolved } \\
\text { around BIM } \\
\text { - The design process has evolved } \\
\text { with BIM }\end{array}$ & $\begin{array}{l}\text { - The appointment of a BIM manager } \\
\text { and coordinator in turn impacts on } \\
\text { organisational structure and } \\
\text { relationships } \\
\text { - Individual roles have also expanded } \\
\text { (with expanded job descriptions) } \\
\text { - Some job descriptions like tracers } \\
\text { are "starting to fall away." }\end{array}$ & $\begin{array}{l}\text { - Team structural hierarchy was } \\
\text { altered because BIM managers } \\
\text { level of leadership is very close to } \\
\text { that of an Architect, if not second } \\
\text { to the architect }\end{array}$ \\
\hline Q8: ARCHITECT & $\begin{array}{l}\text { - The sequence of the design detailing } \\
\text { (you delve into more detail quite } \\
\text { quickly } \\
\text { - The structure of the company's } \\
\text { processes were organised around BIM } \\
\text { modelling workflow }\end{array}$ & $\begin{array}{l}\text { - There is a lot more work done in } \\
\text { the early stages than previously } \\
\text { - It changed how information was } \\
\text { shared among team members }\end{array}$ & $\mathrm{n} \backslash \mathrm{a}$ & $\begin{array}{l}\text { Fee scale structure needs to } \\
\text { evolve with new demands** }\end{array}$ \\
\hline $\begin{array}{l}\text { Q9: ARCHITECT \& } \\
\text { DIRECTOR }\end{array}$ & - $n \backslash a$ & $\begin{array}{l}\text { No real change because existing } \\
\text { processes are well established }\end{array}$ & - $n \backslash a$ & $\begin{array}{l}\text { - Better interaction among team } \\
\text { members }\end{array}$ \\
\hline $\begin{array}{l}\text { Q10: } \\
\text { CIVIL/STRUCTUR } \\
\text { AL ENGINEER \& } \\
\text { DIRECTOR }\end{array}$ & $\begin{array}{l}\text { - Implementing BIM has altered work } \\
\text { sequence }\end{array}$ & - $\mathrm{n} / \mathrm{a}$ & - $n \backslash a$ & - $\mathrm{n} / \mathrm{a}$ \\
\hline
\end{tabular}




\begin{tabular}{|c|c|c|c|c|}
\hline \multirow{2}{*}{ PARTICIPANTS } & \multicolumn{2}{|c|}{ PROCEDURAL CHANGES } & \multicolumn{2}{|c|}{ SOCIAL-CULTURAL CHANGES } \\
\hline & WITHIN ORGANISATIONS & WITHIN TEAMS & WITHIN ORGANISATIONS & WITHIN TEAMS \\
\hline $\begin{array}{l}\text { Q11: ARCHITECT } \\
\text { \& BIM } \\
\text { COORDINATOR }\end{array}$ & $\begin{array}{l}\text { - BIM drives a different design workflow } \\
\text { - Pre-prepared BIM guidelines \& } \\
\text { drawing templates are such that it } \\
\text { prompts on a new method of working } \\
\text { - The printing process is less tedious } \\
\text { with BIM } \\
\text { - Within the organisation it is possible } \\
\text { for several designers to work off a } \\
\text { central file in the same environment }\end{array}$ & $\begin{array}{l}\text { - } \text { BIM is being made a requirement at } \\
\text { the tendering stage for contractors } \\
\text { - Contractors are involved early in } \\
\text { the delivery process } \\
\text { - Certain tasks are shifted }\end{array}$ & $\begin{array}{l}\text { - Working with central files impacts } \\
\text { on interrelationships within the } \\
\text { organisations } \\
\text { - The appointment of a BIM manager } \\
\text { and coordinator (impacts on } \\
\text { organisational interrelationships) } \\
\text { - Individual roles have also expanded } \\
\text { (with expanded job descriptions) } \\
\text { - Implementing BIM has impacted on } \\
\text { the way the work teams are } \\
\text { structured within the organisation } \\
\text { - Some job descriptions like Tracers } \\
\text { are "starting to fall away" }\end{array}$ & $\begin{array}{l}\text { - New roles created and therefore } \\
\text { impact on lines of } \\
\text { communication and interaction } \\
\text { among project team members } \\
\text { - Team structural hierarchy was } \\
\text { altered because new BIM roles } \\
\text { were created }\end{array}$ \\
\hline
\end{tabular}

$\mathrm{n} / \mathrm{a}=$ only accounts of actual experiences were sought, so $\mathrm{n} / \mathrm{a}$ means no change was experienced $* *=$ These are not experiences but participants' perceptions of what should happen 